\title{
The Human Experience with Intravenous Levodopa
}

\author{
Shan H. Siddiqi ${ }^{1}$, Natalia K. Abraham ${ }^{2}$, Christopher L. Geiger ${ }^{3}$, Morvarid Karimi ${ }^{4}$, \\ Joel S. Perlmutter ${ }^{5}$ and Kevin J. Black ${ }^{6 *}$

\begin{abstract}
'Department of Psychiatry, Washington University School of Medicine, St. Louis, MO, USA, ${ }^{2}$ School of Epidemiology, Public Health and Preventive Medicine, University of Ottawa, Ottawa, ON, Canada, ${ }^{3}$ Department of Internal Medicine, University of Washington, Seattle, WA, USA, ${ }^{4}$ Department of Neurology, Washington University School of Medicine, St. Louis, MO, USA, ${ }^{5}$ Programs in Occupational Therapy and Physical Therapy, Division of Biology and Biomedical Sciences, Departments of Neurology, Radiology, and Anatomy and Neurobiology, Washington University School of Medicine, St. Louis, MO, USA, ${ }^{6}$ Division of Biology and Biomedical Sciences, Departments of Psychiatry, Neurology, Radiology, and Anatomy and
\end{abstract} \\ Neurobiology, Washington University School of Medicine, St. Louis, MO, USA
}

Objective: To compile a comprehensive summary of published human experience with levodopa given intravenously, with a focus on information required by regulatory agencies.

Edited by:

Andrew C. McCreary, Janssen Prevention Center Netherlands

Reviewed by: Doris Doudet, University of British Columbia, Canada Kaustuv Saha,

University of Florida, USA

*Correspondence: Kevin J. Black kevin@wustl.edu

Specialty section: This article was submitted to

Neuropharmacology,

a section of the journal

Frontiers in Pharmacology

Received: 21 September 2015 Accepted: 11 December 2015

Published: 06 January 2016

Citation:

Siddiqi SH, Abraham NK, Geiger CL, Karimi M, Perlmutter JS and Black KJ

(2016) The Human Experience with Intravenous Levodopa.

Front. Pharmacol. 6:307.

doi: 10.3389/fphar.2015.00307
Background: While safe intravenous (IV) use of levodopa has been documented for over 50 years, regulatory supervision for pharmaceuticals given by a route other than that approved by the U.S. Food and Drug Administration (FDA) has become increasingly cautious. If delivering a drug by an alternate route raises the risk of adverse events, an investigational new drug (IND) application is required, including a comprehensive review of toxicity data.

Methods: Over 200 articles referring to IV levodopa were examined for details of administration, pharmacokinetics, benefit, and side effects.

Results: We identified 142 original reports describing IVLD use in humans, beginning with psychiatric research in 1959-1960 before the development of peripheral decarboxylase inhibitors. At least 2760 subjects have received IV levodopa, and reported outcomes include parkinsonian signs, sleep variables, hormone levels, hemodynamics, CSF amino acid composition, regional cerebral blood flow, cognition, perception and complex behavior. Mean pharmacokinetic variables were summarized for 49 healthy subjects and 190 with Parkinson's disease. Side effects were those expected from clinical experience with oral levodopa and dopamine agonists. No articles reported deaths or induction of psychosis.

Conclusion: At least 2760 patients have received IV levodopa with a safety profile comparable to that seen with oral administration. 


\section{INTRODUCTION}

Impairments in dopaminergic neurotransmission in the basal ganglia are a hallmark of Parkinson disease (PD), the second most common neurodegenerative disease. Replacement of dopamine has been the cornerstone of treatment for PD. Because dopamine itself does not cross the blood-brain barrier (BBB), its immediate precursor levodopa (L-3,4-dihydroxphenylalanine, L-DOPA) is administered since it crosses the BBB (Hornykiewicz, 1963; Cotzias et al., 1967; Birkmayer and Hornykiewicz, 2001). Although purified levodopa was first ingested by mouth in 1913 (Roe, 1997), it was first used for medical treatment by intravenous (IV) rather than oral administration (Pare and Sandler, 1959; Birkmayer and Hornykiewicz, 2001).

Oral levodopa has become the preferred method of treatment clinically, but IV levodopa administration still holds advantages over the oral form for some purposes. First, the rapid administration of IV levodopa is often necessary for certain study designs, including those focused on the pharmacokinetics and pharmacodynamics of the drug. Additionally, the IV route leads to more predictable plasma levodopa concentration because oral medications have highly variable absorption characteristics, especially in PD patients (Bushmann et al., 1989), with differences in absorption based on sex and age (Robertson et al., 1989; Kompoliti et al., 2002). IV administration also permits researchers to keep brain levodopa concentrations constant while assessing physiological responses over time. Recent years have seen increasing interest in potential benefits of continuous dopaminergic stimulation in the treatment of PD (Jenner et al., 2011). Continuous stimulation helps avoid wearing off of motor benefit during levodopa nadirs, and there is also some evidence that it may reduce the risk of, or mitigate, dyskinesias and other peak-dose side effects. Thus, IV levodopa may prove useful for human studies investigating the pathophysiology of continuous vs. pulsatile dopaminergic stimulation in humans. Finally, IV levodopa is sometimes used clinically in patients who cannot tolerate oral medications, such as PD patients during surgery or on total parenteral nutrition.

Current U.S. FDA regulations focus heightened scrutiny on research in which drugs are delivered by a route for which the drug has not been approved. Predictably, in addition to any safety benefits, the heightened scrutiny has created practical obstacles to research with IV levodopa, as described for instance by Rascol et al. (2001, p. 250). Specifically, an IND (Investigational New Drug) application must be submitted if the risks of IV administration significantly exceed those of oral levodopa [ $\$ 21$ CFR 312.2(b)(iii)]. Therefore, the overall goal of this paper is to determine whether or not IV levodopa carries risks greater than oral administration by compiling a literature review that comprehensively summarizes the human experience with intravenously administered levodopa. We tabulate the extent of human exposure, side effects, benefits, and efficacy. We also summarize pharmacokinetic (PK) and pharmacodynamic (PD) parameters from these studies. These data should help inform decisions about whether IV administration of levodopa requires an IND.

\section{METHODS}

The authors searched MEDLINE and OVID, reviewed selected books, searched toxicity databases, and followed references cited in those sources. Articles written completely in languages other than English, French, German, Italian, Spanish, or Portuguese were excluded. Search terms included (levodopa/L-dopa/DOPA) AND (intravenous/intravascular/infusion/injection/i.v.); limit to humans; search date through May, 2015. Studies using oral or intraduodenal l-DOPA administration were excluded except for PK/PD studies cited in Table 2. Studies in which IV levodopa was always coadministered with monoamine oxidase inhibitors (MAOIs) or catechol-O-methyltransferase (COMT) inhibitors were excluded. Levodopa methyl ester (Juncos et al., 1987) and d,l-DOPA (Pare and Sandler, 1959) were included, but PK/PD calculations were corrected for the difference in molecular weights. Co-administered drugs were reported if included by the authors.

We recorded total dose and maximum infusion rate. We also recorded pharmacokinetic (PK) and pharmacodynamic (PD) parameters where available, including steady state volume of distribution (VOD), clearance, distribution half life $\left(t_{1 / 2 \alpha}\right)$, elimination half life $\left(t_{1 / 2}\right.$ or $\left.t_{1 / 2 \beta}\right), E_{\max }$, and $E C_{50}$. Reported data were used to calculate any missing PK parameters where possible. Additionally, any reports on efficacy were noted. Side effect frequency was recorded if reported. The number of subjects and subject conditions (Parkinson disease, other disease states or healthy volunteers) were recorded for each study. Average PK parameters were calculated across studies, weighted by the number of subjects.

\section{RESULTS}

One hundred forty-two articles reporting intravenous levodopa administration were identified. Most subjects with parkinsonism were diagnosed with idiopathic PD, but some studies reported a variety of etiologies including postencephalitic and vascular parkinsonism and PSP. PD patients differed in their history of prior drug treatment before the studies with conditions including de novo, fluctuating, on-off, and stable. Some subjects were treated with levodopa for conditions other than PD (see Table 1: Patient Populations and Response Parameters), including other movement disorders (dystonia, progressive supranuclear palsy [PSP], neuroleptic malignant syndrome [NMS], primary psychiatric disorders (schizophrenia, mood disorders, personality disorders), endocrine disorders (diabetes mellitus, essential obesity, hypopituitarism), hepatic disease (alcoholic cirrhosis, steatohepatitis, hepatic encephalopathy), cardiac valvular disease, and asthma. Healthy controls were also included in some studies.

Pharmacokinetic data were reported for a total of 251 human subjects (see Table 2: Pharmacokinetics of Levodopa). Co-administration of a peripheral decarboxylase inhibitor (PDI) lowered the clearance and increased the elimination half-life of intravenously administered levodopa, while there was no notable effect of PDIs on volume of distribution. Additional PK data are available from studies that gave levodopa by 
TABLE 1 | Patient populations and response parameters.

\begin{tabular}{|c|c|}
\hline Patient populations & Response parameters \\
\hline Healthy volunteers & Vital signs: \\
\hline Movement disorders: & Heart rate, blood pressure, \\
\hline Parkinson's (de novo, stable, & temperature, respirations \\
\hline fluctuators, on-off) & Cardiovascular: \\
\hline Progressive supranuclear palsy & ECG \\
\hline Parkinson's disease psychosis & Cerebral blood flow \\
\hline Carcinoma of the rectum & Renal: \\
\hline Stereotactic surgery & Urine flow \\
\hline Post-menopausal women & Urinary sodium excretion \\
\hline Tourette syndrome/tic disorders & Potassium excretion \\
\hline Asthma & Plasma renin activity \\
\hline Schizophrenia & Renal plasma flow \\
\hline Mood disorders: & Metabolism: \\
\hline Mild to moderate depression & Urinary metabolite excretion \\
\hline Treatment-resistant depression & Cerebral metabolism \\
\hline Bipolar depression & Plasma metabolites \\
\hline Cyclothymic disorder & CSF amino-acid composition \\
\hline Borderline personality disorder & PD motor improvement \\
\hline $\begin{array}{l}\text { Neuroleptic malignant } \\
\text { syndrome }\end{array}$ & $\begin{array}{l}\text { Unified Parkinson's disease rating } \\
\text { scale (UPDRS), walking, tapping, etc. }\end{array}$ \\
\hline Hepatic disorders: & Dyskinesias \\
\hline Alcoholic cirrhosis & Tic improvement \\
\hline Steatohepatitis & Neuropsychiatric: \\
\hline Hepatic encephalopathy & Cognition \\
\hline Endocrine disorders: & Mood \\
\hline Diabetes mellitus & Behavior \\
\hline Essential obesity & Psychosis \\
\hline Hypopituitarism & Dementia \\
\hline Cardiovascular disease: & EEG (including REM sleep EEG) \\
\hline Atrial septal defect & Endocrine: \\
\hline Rheumatic valvular disease & $\begin{array}{l}\text { Prolactin, HGH, ACTH, LH, } \\
\text { vasopressin }\end{array}$ \\
\hline
\end{tabular}

Subject populations given IV levodopa and responses to drug measured in studies listed in Table 3.

other routes (Sasahara et al., 1980a; Poewe, 1993; Muhlack et al., 2004; LeWitt et al., 2009), and several studies report the bioavailability of oral doses relative to IV administration (Sasahara et al., 1980b; Robertson et al., 1989; Kompoliti et al., 2002).

The pharmacodynamic data (see Table 3: Reports of Human Experience with IV Levodopa) represent a total of 2760 human subjects, with a significant variety of patient groups and a multitude of response parameters (see Table 1). No side effects were reported for 1260 subjects. The highest total IV dose was $4320 \mathrm{mg}$ in 1 day, given to a patient with idiopathic PD and carcinoma of the retina. The patient reported no adverse effects at this dose. The highest reported single bolus dose was $200 \mathrm{mg}$, and the highest infusion rate was $5.0 \mathrm{mg} / \mathrm{kg} / \mathrm{h}$.

Concomitantly administered peripheral decarboxylase inhibitors included carbidopa and benserazide. PDIs affected clearance and volume of distribution (as mentioned above), minimized gastrointestinal symptoms, and allowed subjects to be given lower doses of levodopa. Other concomitant drugs are listed, to help explain any side effects that might be caused by concomitant drug administration or an interaction with levodopa rather than by levodopa alone. These include adenosine receptor antagonists (istradefylline, tozadenant [SYN115], aminophylline, caffeine), stimulants (amphetamines, methylphenidate), dopamine receptor agonists (apomorphine, terguride, SKF38393), monoamine oxidase (MAO) inhibitors, dextromethorphan, estradiol, paroxetine, and dantrolene.

A variety of neurological, psychiatric, cardiovascular, and other physiological effects of levodopa were monitored (see Table 1). There were no reported deaths. There were no instances of psychosis, even when attempting to elicit it in susceptible subjects (Goetz et al., 1998). There were also no life-threatening events (serious adverse effects) following IV levodopa administration at high doses, regardless of whether a PDI was co-administered. With co-administration of a PDI, the dosage range causing side effects (mainly nausea and asymptomatic hypotension) was $45-150 \mathrm{mg}$ as a single bolus or infusions of $0.5-2.0 \mathrm{mg} / \mathrm{kg} / \mathrm{h}$. Without a co-administered PDI, side effects were reported with a bolus of $60-200 \mathrm{mg}$ or an infusion of $1.5-3.0 \mathrm{mg} / \mathrm{kg} / \mathrm{hr}$. Side effects were more likely with higher doses, but other factors such as age, sex, disease severity, and prior treatment also played a role in side effects of levodopa.

Other than these side effects found at high doses, several milder or less frequent side effects were reported. These primarily included mild autonomic changes (orthostasis and tachycardia), psychiatric changes (sedation, anxiety, insomnia, and improvement in mood), and neurologic effects (improvements in tics, REM sleep changes, subjective weakness, headaches, and increased dyskinesias). Various other effects were noted in isolated reports (listed in Table 3). It is important to note that both side effects and efficacy depended strongly on subject factors including gender, age, past treatment, and disease state. Also, dsykinesia was mentioned as a side effect only in patients with PD, and most often in those with a long history of previous levodopa treatment.

Motor benefits of levodopa in PD have been demonstrated conclusively. Additional reported benefits of IV levodopa treatment in PD included improved sleep (Hardie et al., 1984) and attenuation of early morning akinesia or dystonia (Juncos et al., 1987). In other patient groups, benefits of IV levodopa included improvement of the comatose state in hepatic encephalopathy (Abramsky and Goldschmidt, 1974) and improvement in depressive and somatoform symptoms (Ingvarsson, 1965a). One report found it more effective than dantrolene for treating neuroleptic malignant syndrome (Nisijima et al., 1997). More recently, IV levodopa treatment was found to alleviate the neuropsychiatric adverse effects associated with interferon-alpha, namely lethargy, hypersomnia, depression, agitation, akathisia, and confusion (Sunami et al., 2000). 
TABLE 2 | Pharmacokinetics of levodopa.

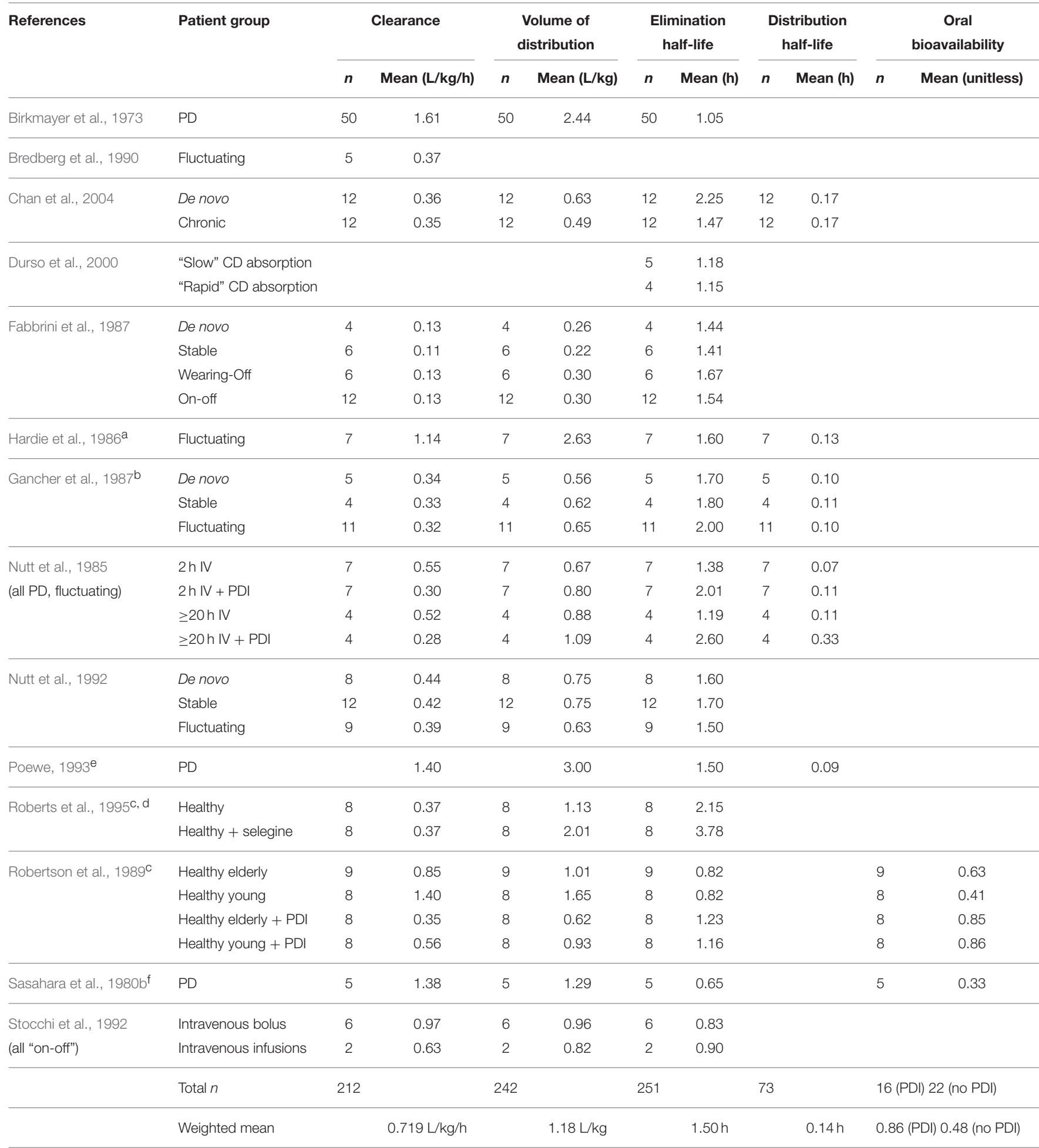

Summary of pharmacokinetic parameters with weighted means.

${ }^{a}$ Assumed mean weight to be $70 \mathrm{~kg}$ for VOD.

${ }^{b}$ Values read from graphs.

${ }^{c}$ Half-life estimated from relationship: clearance $=\left(\operatorname{In} 2{ }^{*}\right.$ VOD $) /$ elim. T1/2.

${ }^{d}$ Assumed mean weight to be $70 \mathrm{~kg}$ for clearance.

efrom a table with no additional data provided; not included in weighted mean calculations of pharmacokinetic parameters.

${ }^{f} V O D$ estimated from relationship: clearance $=\left(\ln 2{ }^{*}\right.$ VOD $) /$ elim. T1/2. 


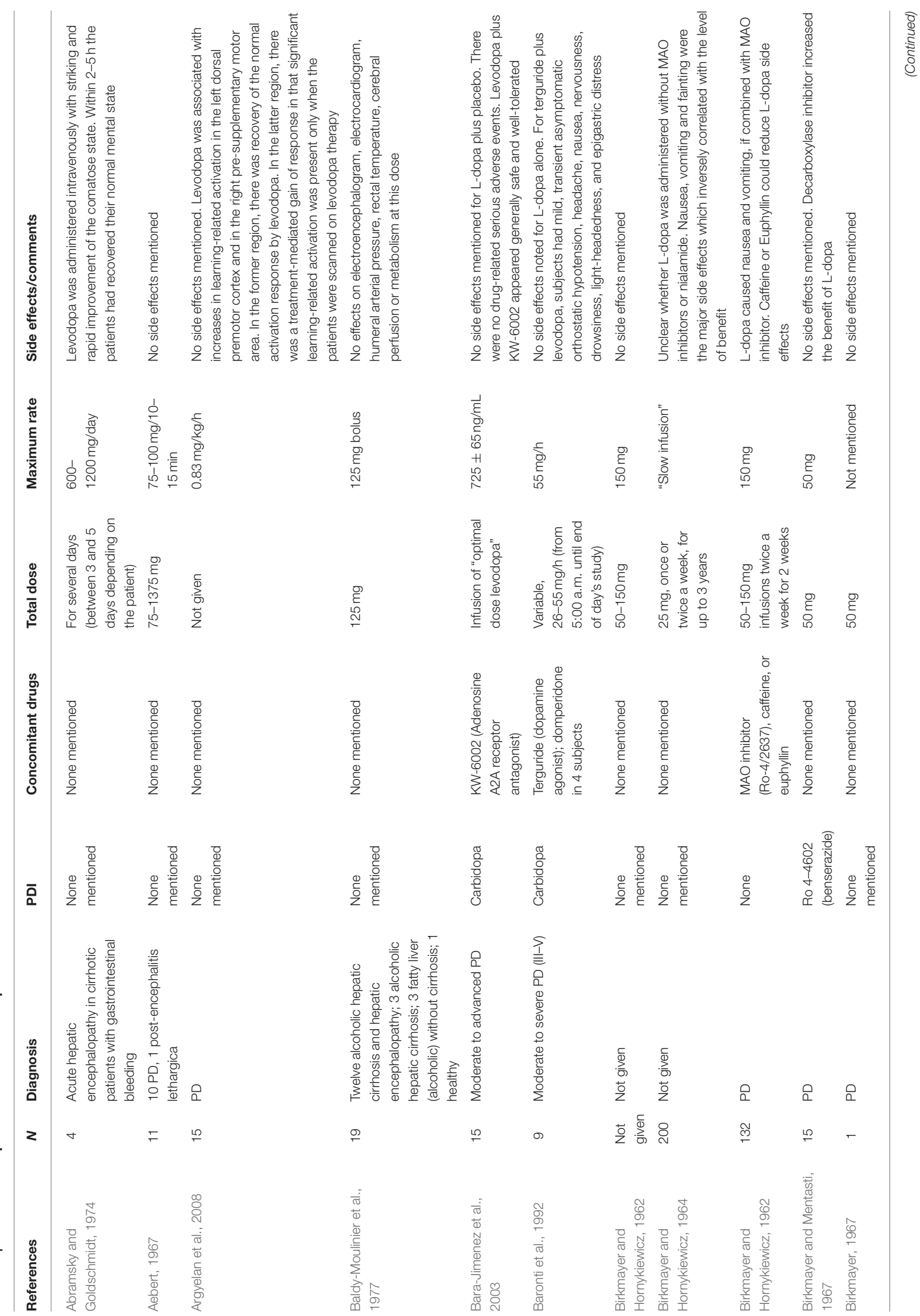




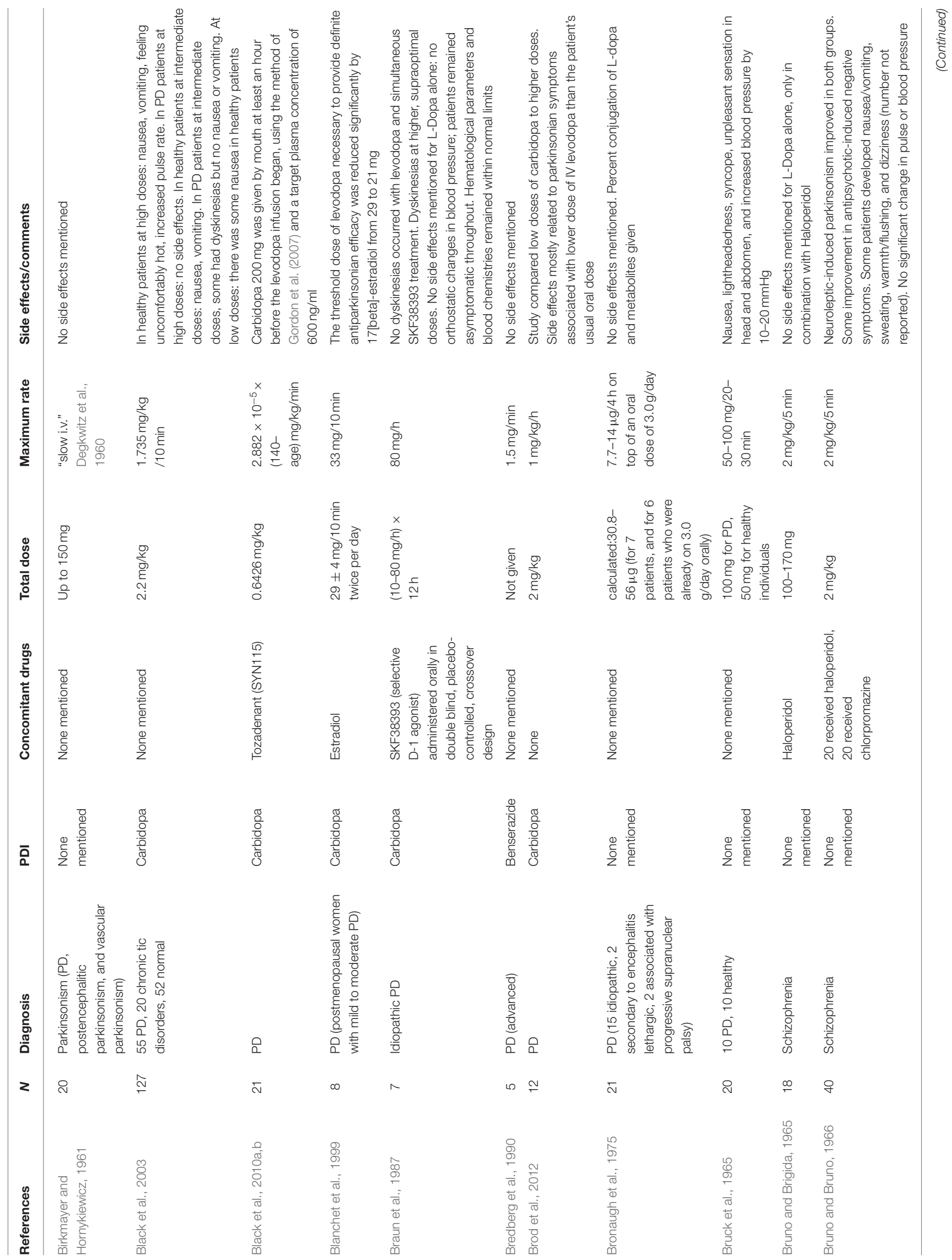




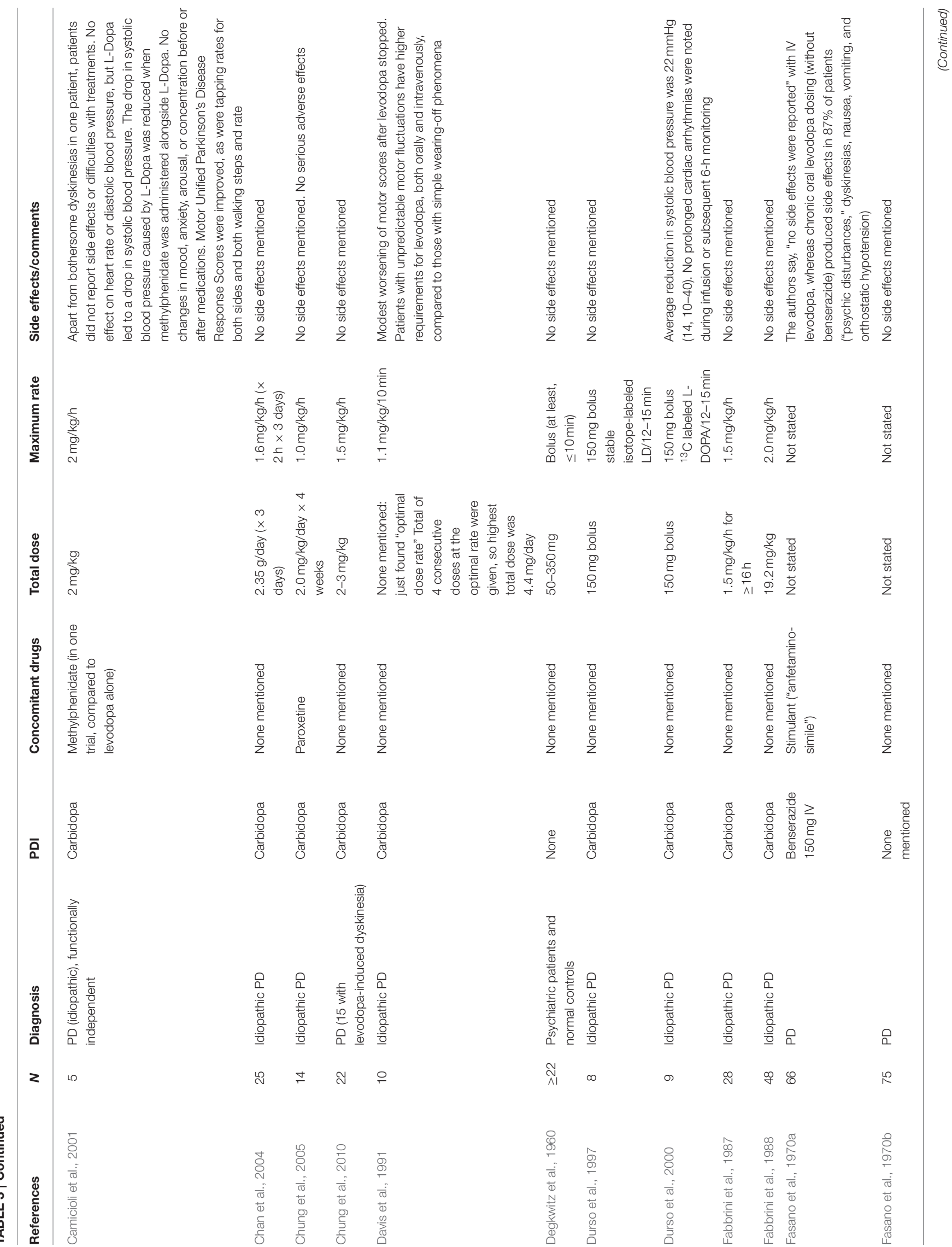




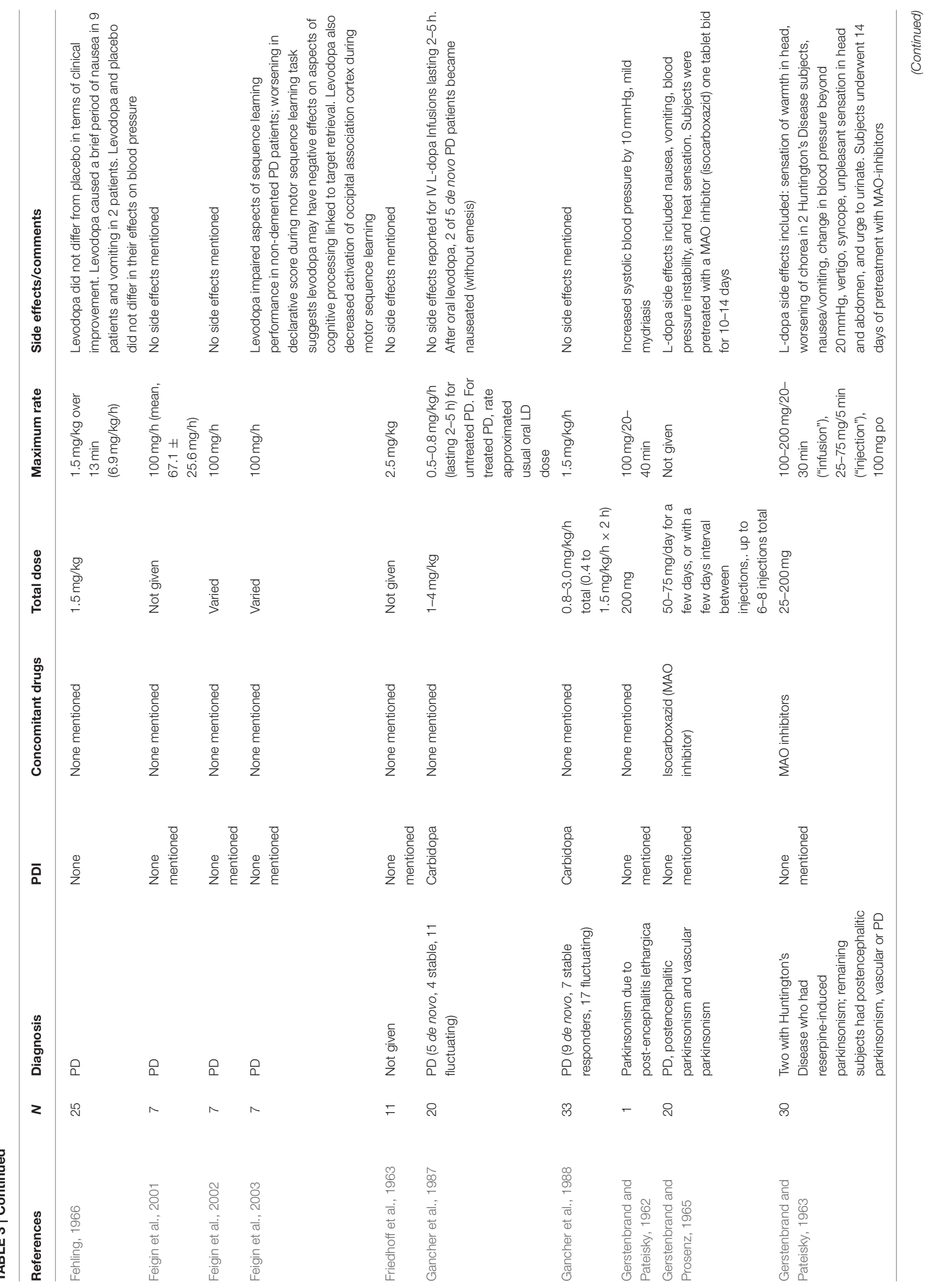




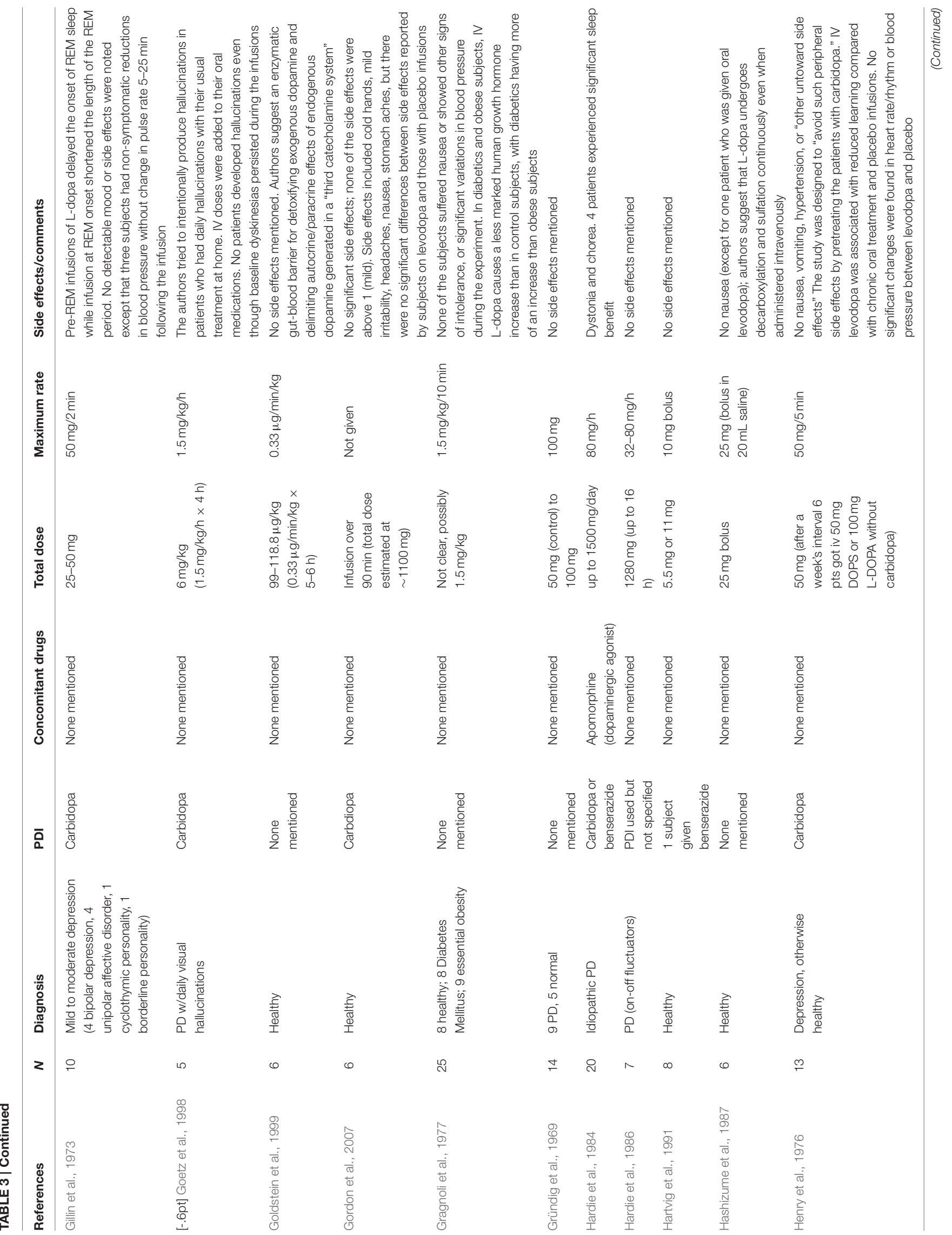



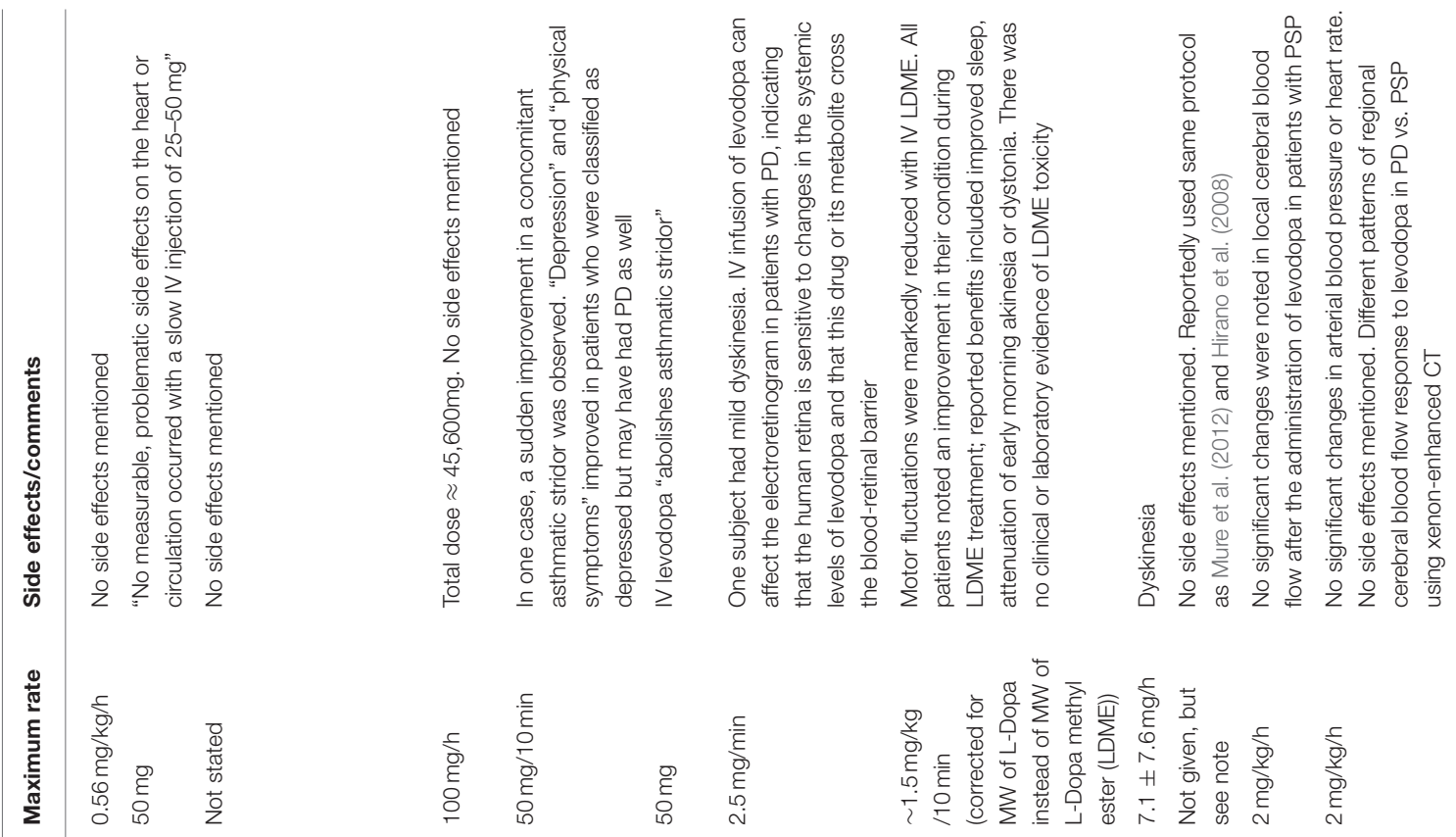

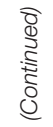
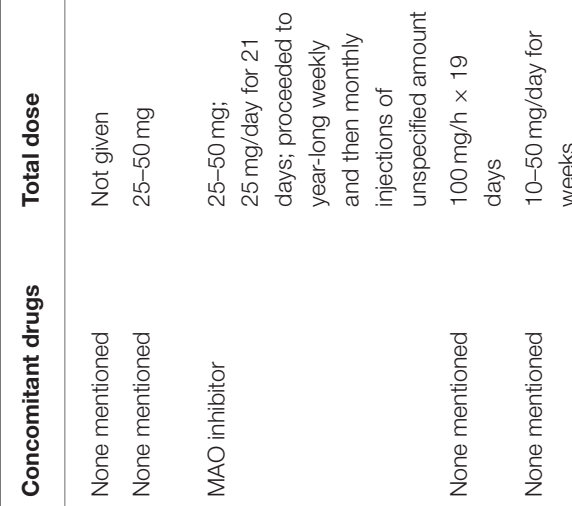

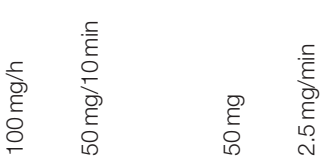

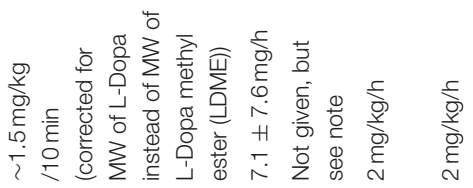

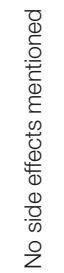

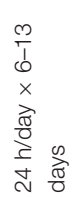

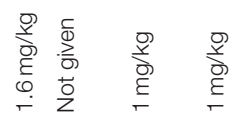

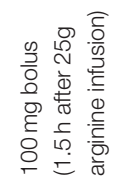

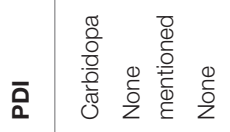

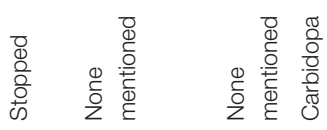

$\frac{\pi}{\frac{0}{0}}$

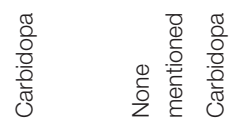

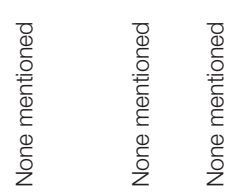

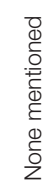
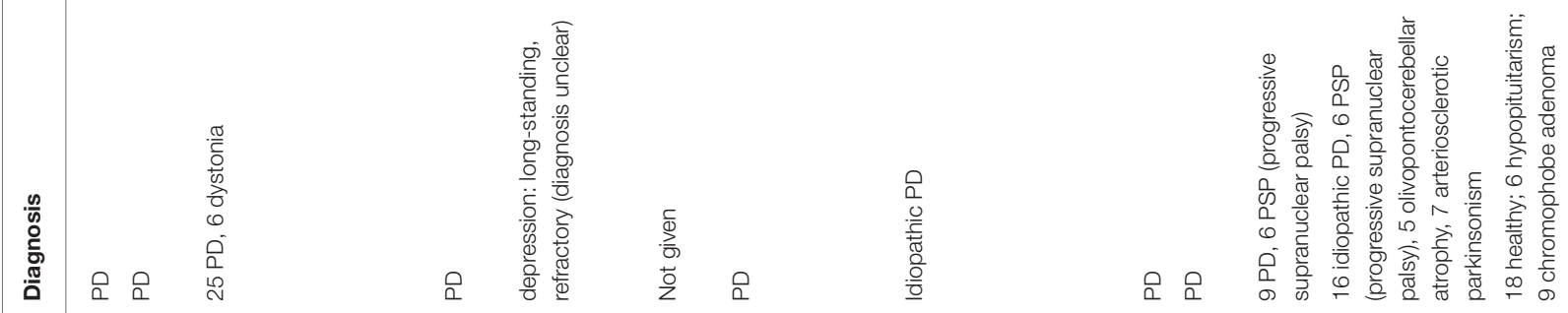

$z$ 웅

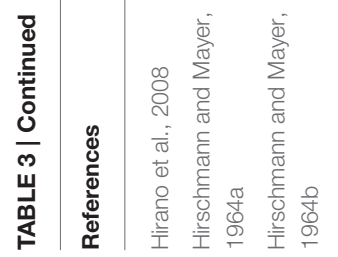
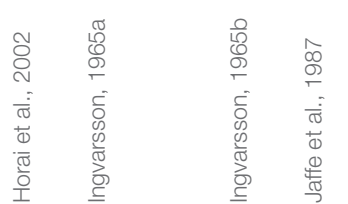

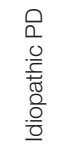

올

$\stackrel{ }{\leftarrow} \stackrel{\circ}{\leftarrow}$

m 


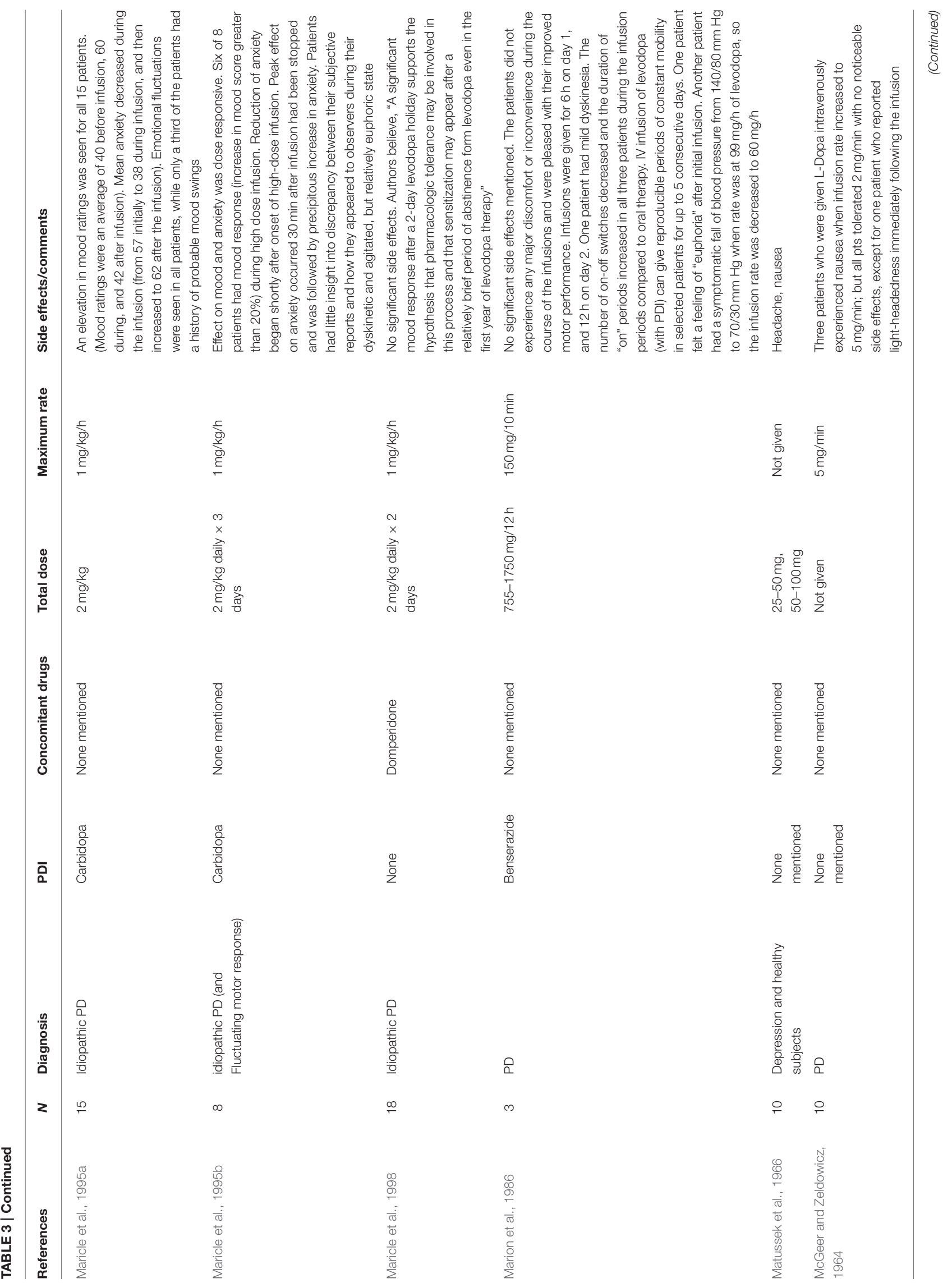



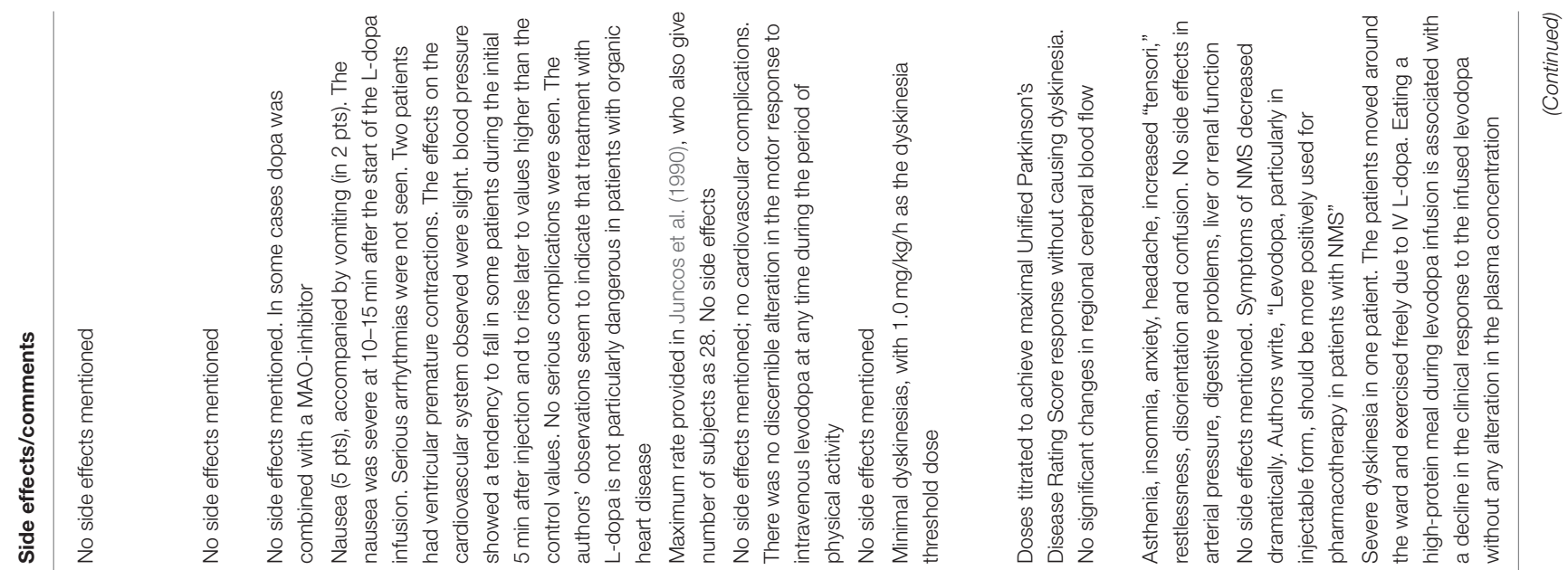

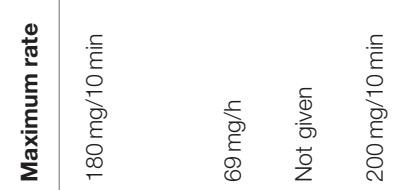

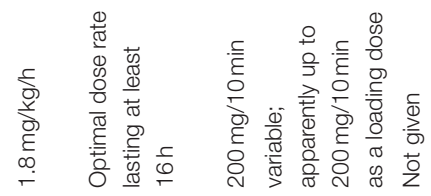

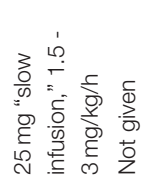

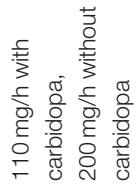

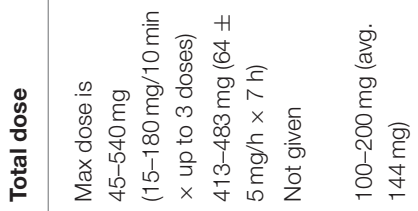

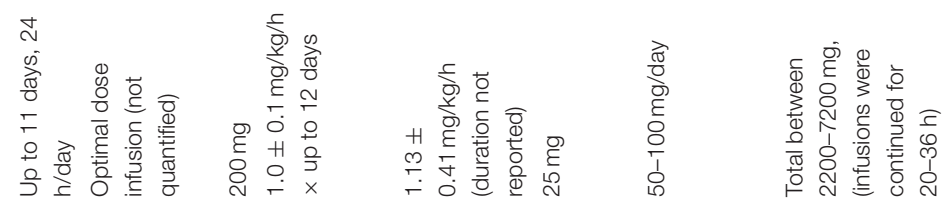
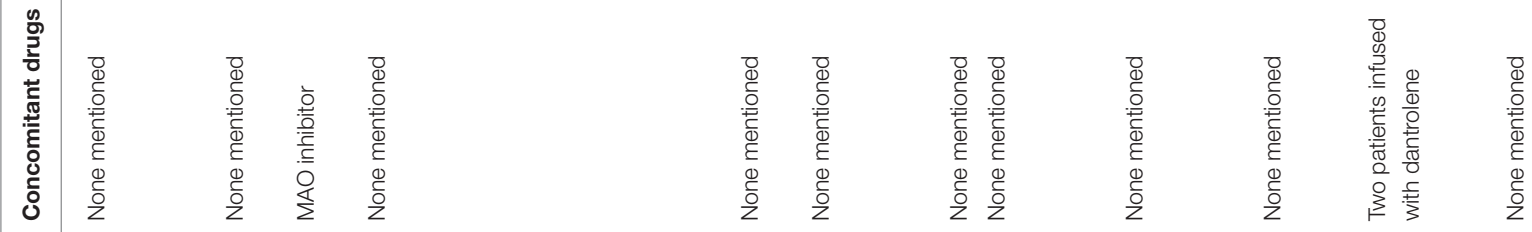

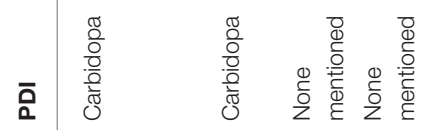

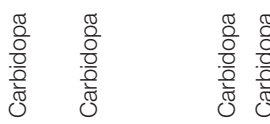

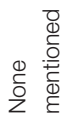

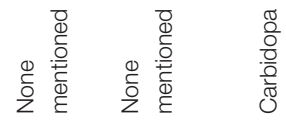

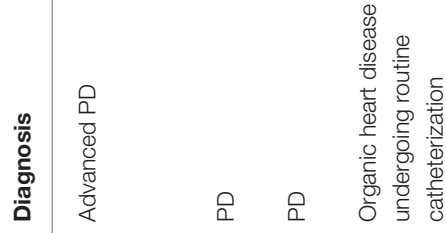

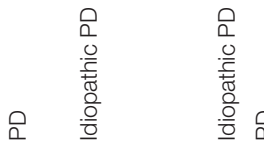

z $\stackrel{\leftrightarrow}{N} \quad \forall \quad \overline{6} \infty$

$\stackrel{\infty}{\sim}$

$\stackrel{2}{N}$

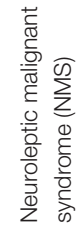

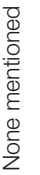

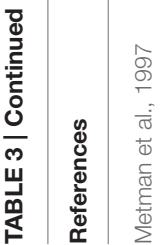

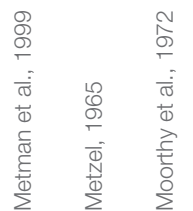

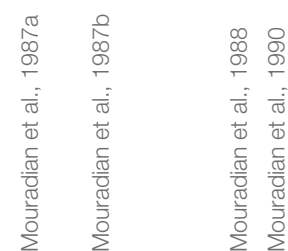

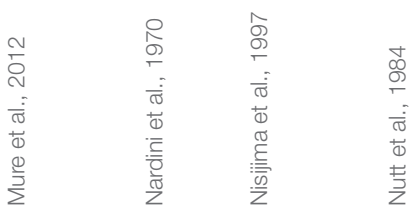




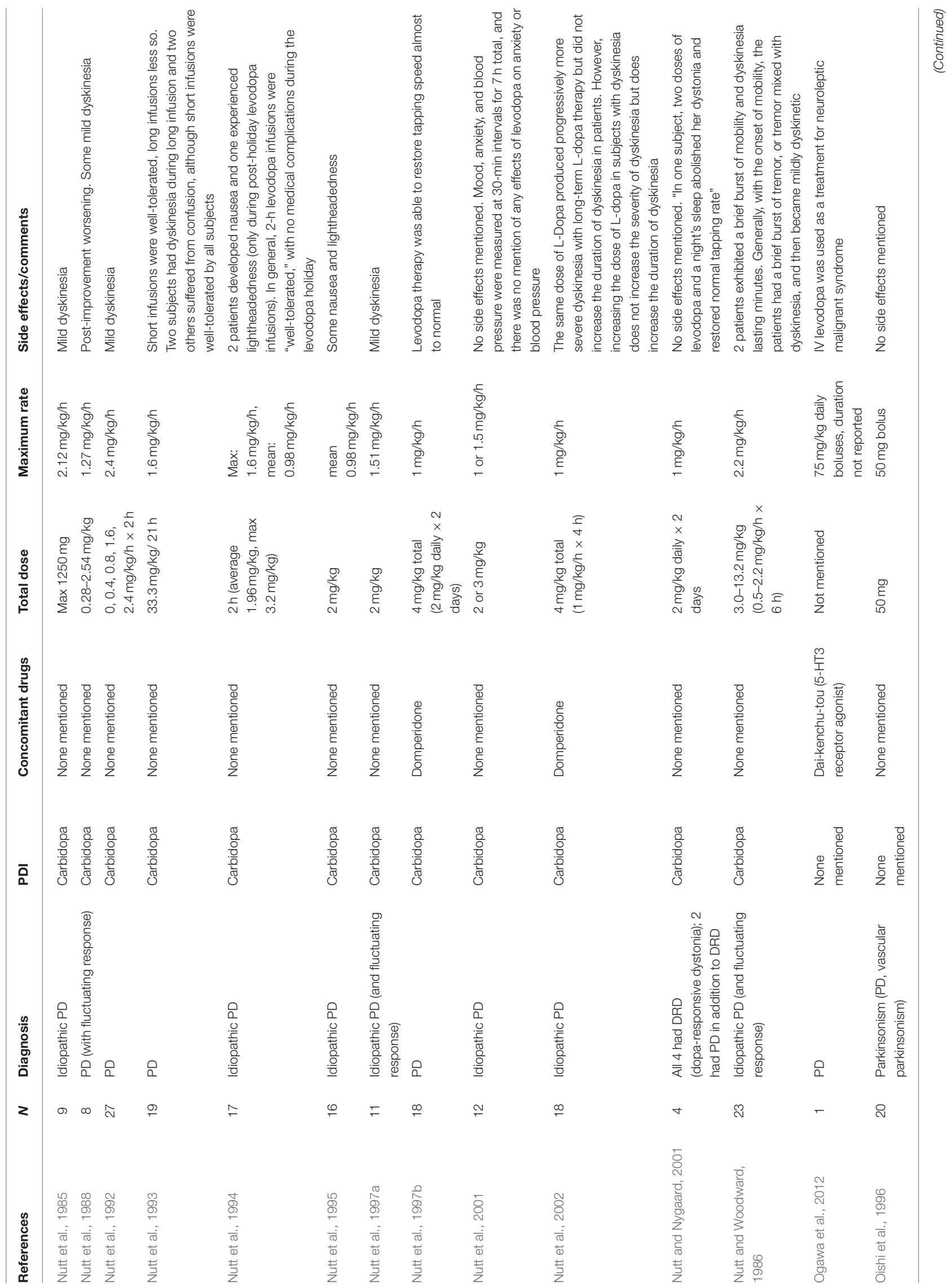




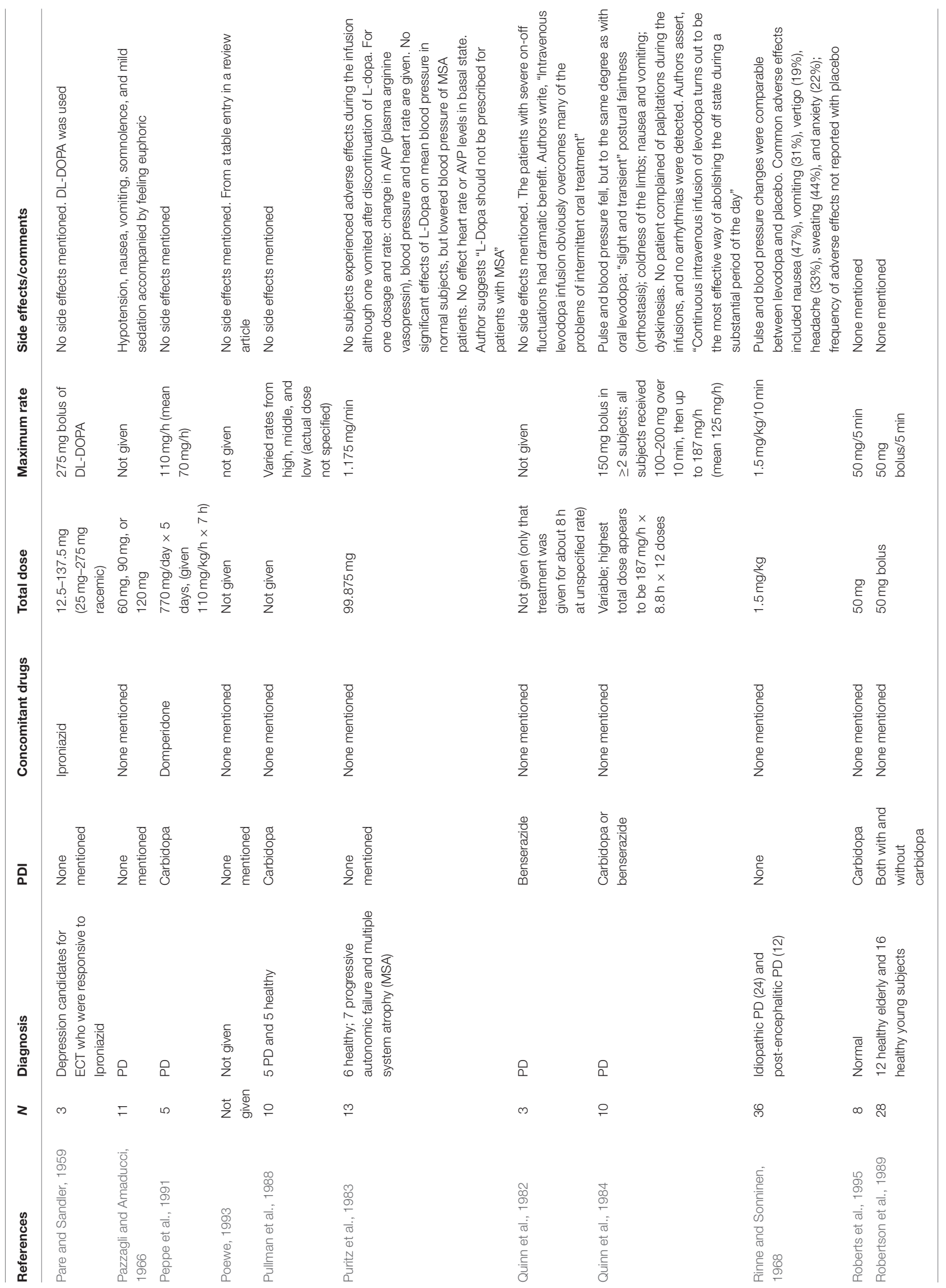




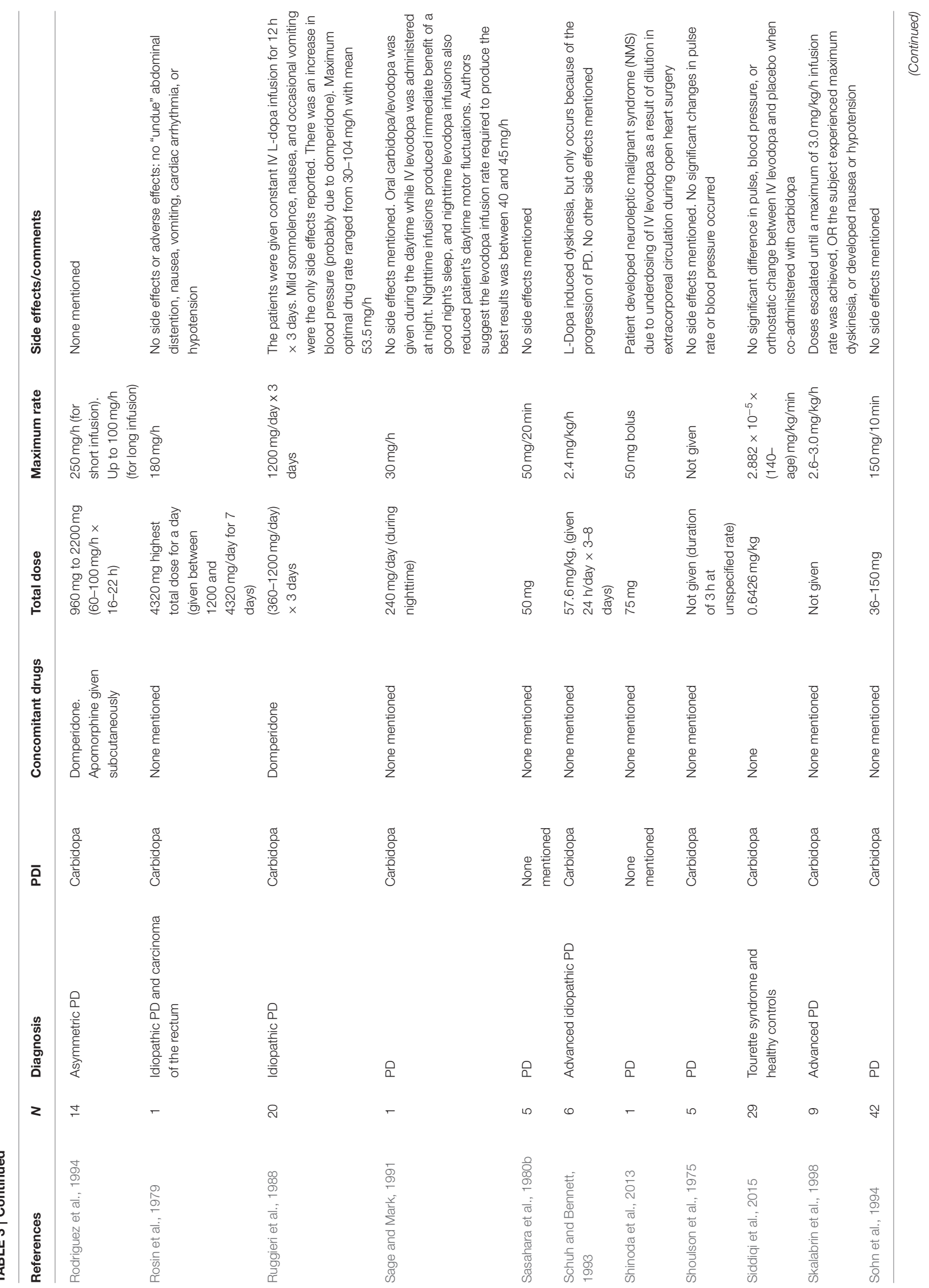




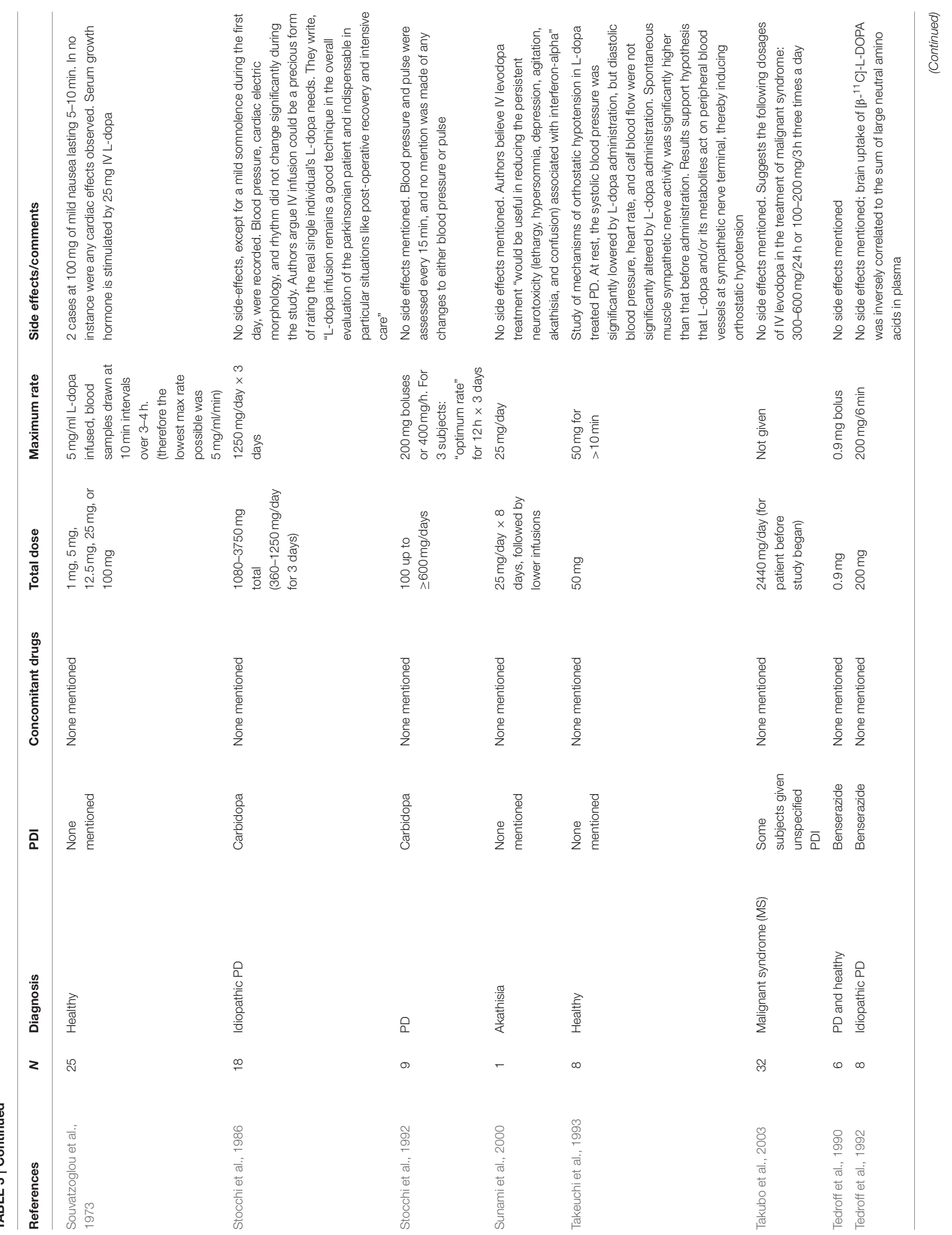



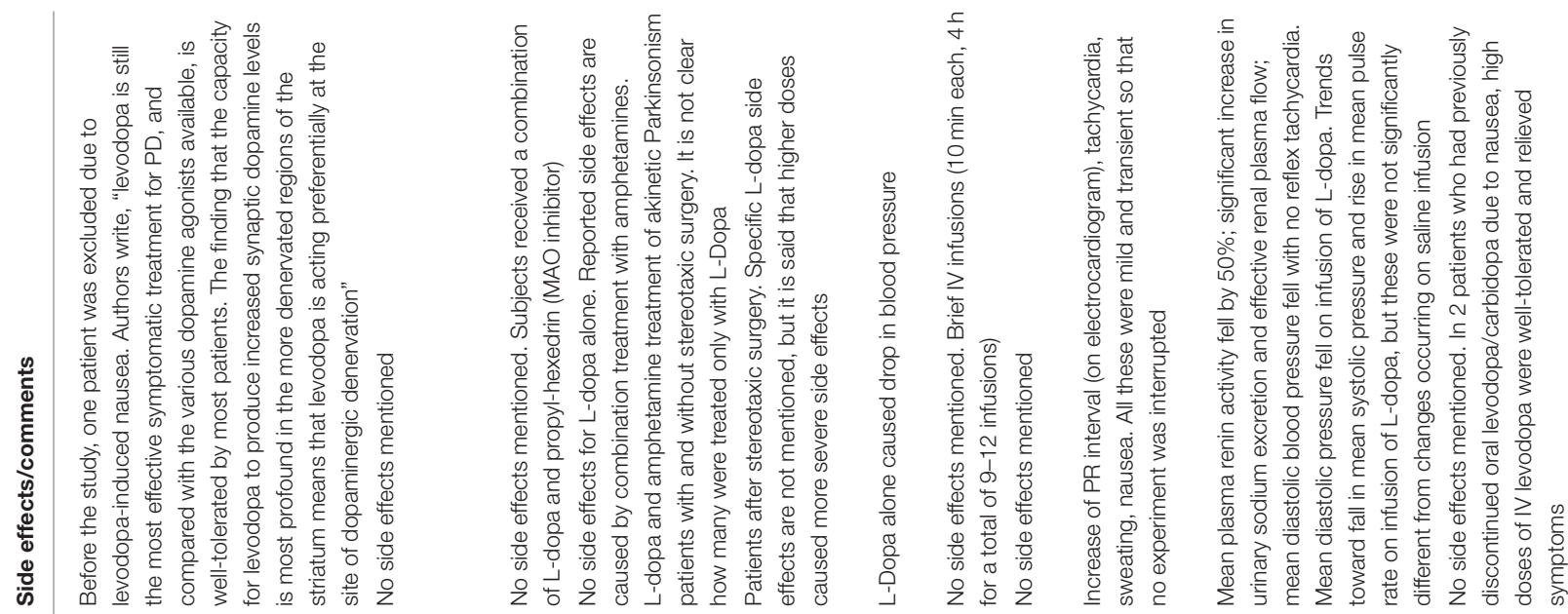

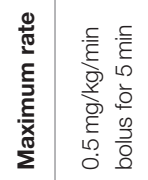

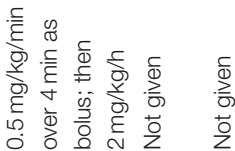

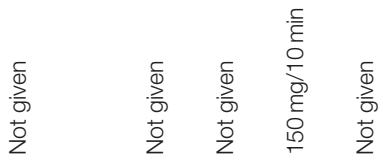

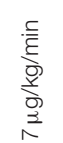

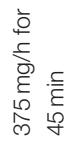

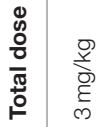

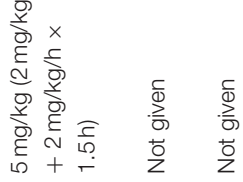

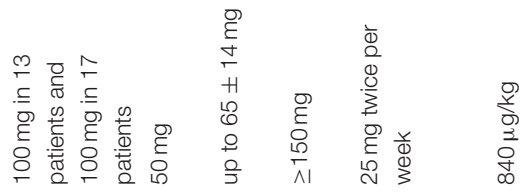

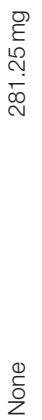

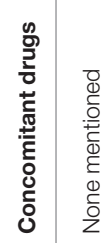
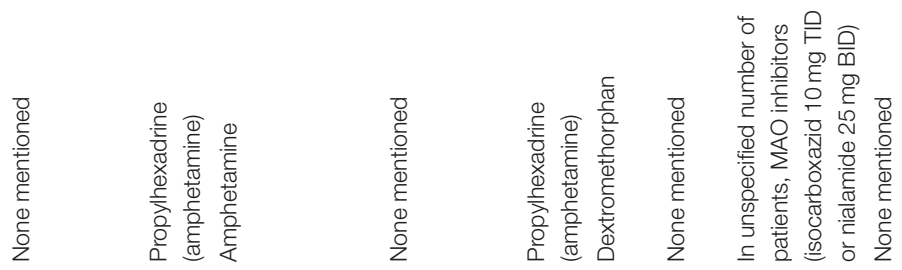

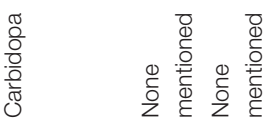

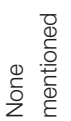

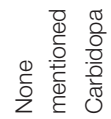

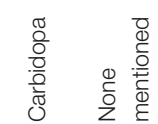

竞

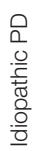

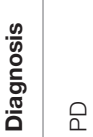

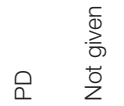

용 蒙

$z$ 우

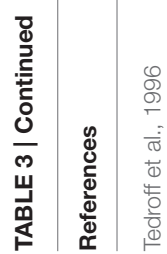

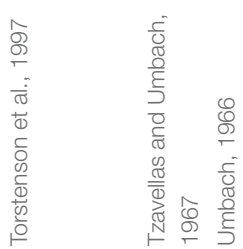

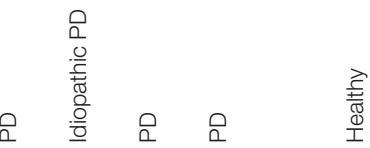

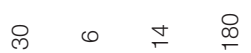

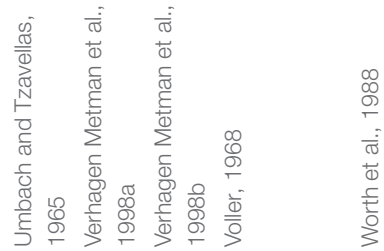

$\frac{0}{0}$
$\frac{0}{2}$
0
0
0
0
0
0
0

œ

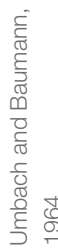

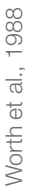

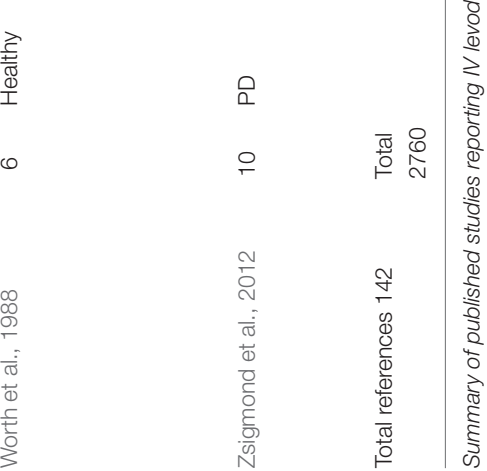




\section{DISCUSSION}

The existing literature strongly supports the safety of IV levodopa, which has been used in humans for more than half a century (Pare and Sandler, 1959). IV levodopa has been administered to over 2700 human subjects. Despite infusion rates as high as $5.0 \mathrm{mg} / \mathrm{kg} / \mathrm{h}$ and boluses as large as $200 \mathrm{mg}$, there are no recorded instances of death or of other serious adverse effects of IV levodopa, nor have there been documented cases of other serious side effects, such as psychosis, that might limit its use in humans. Milder side effects, the most significant of which are nausea and vomiting, were most prominent with rapid infusions in the range of $1-2 \mathrm{mg} / \mathrm{kg}$ or $100-200 \mathrm{mg}$ over less than $15 \mathrm{~min}$ (Bruno and Bruno, 1966; Fehling, 1966; Rinne and Sonninen, 1968; Moorthy et al., 1972; Quinn et al., 1984; Black et al., 2003).

These conclusions are supported by safety data from other species. The Registry of Toxic Effects of Chemical Substances reports the lowest published toxic dose of levodopa in any nonhuman species as $2.5 \mathrm{mg} / \mathrm{kg}$, referring to a subtle behavioral effect on a learning measure in a mouse (NIOSH and Biovia, 2015) $)^{1}$. The lowest IV levodopa dose that was lethal to half of subjects (LD50) was " $>100 \mathrm{mg} / \mathrm{kg}$ " in rats. In mice, the LD50 ranges from $450 \mathrm{mg} / \mathrm{kg}$ (administered intravenously) to $4449 \mathrm{mg} / \mathrm{kg}$ (administered subcutaneously). Typical human doses are in the range of only $1 \mathrm{mg} / \mathrm{kg}$; thus, human studies with IV levodopa administer doses substantially lower than those dangerous to nonhuman mammals.

In summary, IV levodopa has similar efficacy and side effects as oral levodopa (Connolly and Lang, 2014) and dopamine agonists (Bonuccelli and Ceravolo, 2008). These include gastrointestinal (nausea, vomiting, and abdominal discomfort) and neuropsychiatric effects (sedation, dyskinesias). Nausea and orthostatic hypotension, side effects of both IV and

${ }^{1}$ RTECS reported the lowest toxic dose as " $100 \mu \mathrm{g} / \mathrm{kg}$," but the dose in the cited reference was actually $100 \mu \mathrm{g} / \mathrm{g}=100 \mathrm{mg} / \mathrm{kg}$ (Takahara et al., 1980).

oral levodopa, are largely blocked by PDIs and are less common in patients accustomed to dopamimetic treatment. The other side effects are infrequent and neither serious nor life-threatening

\section{REFERENCES}

Abramsky, O., and Goldschmidt, Z. (1974). Treatment and prevention of acute hepatic encephalopathy by intravenous levodopa the dopamine motor system. Surgery 75, 188-191.

Aebert, K. (1967). [What success does L-Dopa have in the treatment of parkinsonian akinesia?]. Dtsch. Med. Wochenschr. 92, 483-487. doi: 10.1055/s0028-1103669

Argyelan, M., Carbon, M., Ghilardi, M. F., Feigin, A., Mattis, P., Tang, C., et al. (2008). Dopaminergic suppression of brain deactivation responses during sequence learning. J. Neurosci. 28, 10687-10695. doi: 10.1523/JNEUROSCI.2933-08.2008

Baldy-Moulinier, M., Bories, P., Michel, H., and Passouant, P. (1977). [Hepatic encephalopathies; hemodynamic and metabolic study of the influence of ammonia and levodopa]. Rev. Neurol. 133, 175-189.

Bara-Jimenez, W., Sherzai, A., Dimitrova, T., Favit, A., Bibbiani, F., Gillespie, M., et al. (2003). Adenosine $A_{2 A}$ receptor antagonist treatment of Parkinson's disease. Neurology 61, 293-296. doi: 10.1212/01.WNL.0000073136.00548.D4
(Connolly and Lang, 2014). When given with adequate PDI pretreatment, IV levodopa has minimal if any cardiovascular effects (Siddiqi et al., 2015).

The safety of IV levodopa is important for patients but also for regulatory review. Changing the route of administration of any drug in a study traditionally necessitates submitting an IND application if changing the route of administration "significantly increases the risks ... associated with the use of the drug product" [ $\$ 21$ CFR 312.2(b)(iii)]. The data from our review of the literature suggest that IV administration of levodopa does not significantly increase the associated risks of levodopa in comparison to oral administration. In summary, studies conducted throughout the past half century support the safety of IV levodopa administration in human patients.

\section{AUTHOR CONTRIBUTIONS}

Literature search: NA, SS, CG, KB. Writing: SS, CG, JP, KB. Statistics: NA, KB. Translation from German: MK. All authors approved the final manuscript.

\section{ACKNOWLEDGMENTS}

The authors gratefully acknowledge the assistance of Claire Devine, J.D. (former affiliation: School of Arts and Sciences, Washington University in St. Louis) and of Beth Beato. Manuscript preparation was funded in part by the National Institutes of Health (K24 MH087913). An early summary of this work was presented at the World Parkinson Congress, Washington, DC, USA, February, 2006 (http://f1000research. com/posters/1097795). A preprint was posted at bioRxiv (doi: 10.1101/024794). National Institutes of Health (K24 MH087913, NS075321, NS041509, NS058714), the Barnes-Jewish Hospital Foundation (the Elliot Stein Family Fund and Parkinson Disease Research Fund), the American Parkinson Disease Association (APDA) Advanced Research Center for Parkinson Disease at Washington University in St. Louis, and the Greater St. Louis Chapter of the APDA.

Baronti, F., Mouradian, M. M., Conant, K. E., Giuffra, M., Brughitta, G., and Chase, T. N. (1992). Partial dopamine agonist therapy of levodopa-induced dyskinesias. Neurology 42, 1241-1243. doi: 10.1212/WNL.42.6.1241

Birkmayer, W. (1967). Die Messung der kinetischen Energie bei Bewegungsvollz. gen [The measurement of kinetic energy in movement accomplishment]. Wien. Med. Wochenschr. 117, 1138-1139.

Birkmayer, W., Danielcyk, W., Neumayer, E., and Riederer, P. (1973). L-dopa level in plasma, primary condition for the kinetic effect. J. Neural Transm. 34, 133-143. doi: 10.1007/BF01244666

Birkmayer, W., and Hornykiewicz, O. (1961). Der L-3,4-Dioxyphenylalanin (=DOPA)-Effekt bei Parkinson-Akinese. Wien. Klin. Wochenschr. 73, 787-788.

Birkmayer, W., and Hornykiewicz, O. (1962). Der L-Dioxyphenylalanin (LDOPA) Effekt beim Parkinson-Syndrom des Menschen: Zur Pathogenese und Behandlung der Parkinson-Akinese [The L-dihydroxyphenylalanine (LDOPA) effect in Parkinson's syndrome in man: On the pathogenesis and treatment of Parkinson akinesis]. Arch. Psychiatr. Nervenkr. Z. Gesamte Neurol. Psychiatr. 203, 560-574. doi: 10.1007/BF00343235 
Birkmayer, W., and Hornykiewicz, O. (1964). [Additional experimental studies on L-DOPA in Parkinson's syndrome and reserpine parkinsonism]. Arch. Psychiatr. Nervenkr. 206, 367-381. doi: 10.1007/BF00341704

Birkmayer, W., and Hornykiewicz, O. (2001). The effect of L-3,4dihydroxyphenylalanine (=DOPA) on akinesia in parkinsonism. (1961). Wien. Klin. Wochenschr. 113, 851-854.

Birkmayer, W., and Mentasti, M. (1967). Weitere experimentelle Untersuchungen ber den Catecholaminstoffwechsel bei extrapyramidalen Erkrankungen (Parkinson- und Chorea-Syndrom) [Further experimental studies on the catecholamine metabolism in extrapyramidal diseases (Parkinson and chorea syndromes)]. Arch. Psychiatr. Nervenkr. 210, 29-35. doi: 10.1007/BF01217333

Black, K. J., Campbell, M. C., Dickerson, W., Creech, M. L., Koller, J. M., Chung, S. C., et al. (2010b). A randomized, double-blind, placebo-controlled cross-over trial of the adenosine 2a antagonist SYN115 in Parkinson disease. Neurology 74, A317-A317. doi: 10.1523/JNEUROSCI.2590-10.2010

Black, K. J., Carl, J. L., Hartlein, J. M., Warren, S. L., Hershey, T., and Perlmutter, J. S. (2003). Rapid intravenous loading of levodopa for human research: clinical results. J. Neurosci. Methods 127, 19-29. doi: 10.1016/S0165-0270(03)00096-7

Black, K. J., Koller, J. M., Campbell, M. C., Gusnard, D. A., and Bandak, S. I. (2010a). Quantification of indirect pathway inhibition by the adenosine $A_{2 a}$ antagonist SYN115 in Parkinson disease. J. Neurosci. 30, 16284-16292. doi: 10.1523/JNEUROSCI.2590-10.2010

Blanchet, P. J., Fang, J., Hyland, K., Arnold, L. A., Mouradian, M. M., and Chase, T. N. (1999). Short-term effects of high-dose 17beta-estradiol in postmenopausal PD patients: a crossover study. Neurology 53, 91-95. doi: 10.1212/WNL.53.1.91

Bonuccelli, U., and Ceravolo, R. (2008). The safety of dopamine agonists in the treatment of Parkinson's disease. Expert Opin. Drug Saf. 7, 111-127. doi: 10.1517/14740338.7.2.111

Braun, A., Fabbrini, G., Mouradian, M. M., Serrati, C., Barone, P., and Chase, T. N. (1987). Selective D-1 dopamine receptor agonist treatment of Parkinson's disease. J. Neural Transm. 68, 41-50. doi: 10.1007/BF01244638

Bredberg, E., Tedroff, J., Aquilonius, S. M., and Paalzow, L. (1990). Pharmacokinetics and effects of levodopa in advanced Parkinson's disease. Eur. J. Clin. Pharmacol. 39, 385-389. doi: 10.1007/BF00315415

Brod, L. S., Aldred, J. L., and Nutt, J. G. (2012). Are high doses of carbidopa a concern? A randomized, clinical trial in Parkinson's disease. Mov. Disord. 27, 750-753. doi: $10.1002 / \mathrm{mds} .24998$

Bronaugh, R. L., MacMurtry, R. J., Hoehn, M. M., and Rutledge, C. O. (1975). Conjugation of L-DOPA and its metabolites after oral and intravenous administration to Parkinsonian patients. Biochem. Pharmacol. 24, 1317-1320. doi: 10.1016/0006-2952(75)90345-7

Bruck, J., Gerstenbrand Gründig, E., and Prosenz, P. (1965). [Metabolic changes in extrapyramidal syndromes and preliminary therapeutic consequences]. Fortschr. Neurol. Psychiatr. Grenzgeb. 33, 677-691.

Bruno, A., and Brigida, E. (1965). [Action of L-DOPA on the extrapyramidal symptomatology of haloperidol]. Riv. Neurobiol. 11, 646-654.

Bruno, A., and Bruno, S. C. (1966). Effects of L-DOPA on pharmacological parkinsonism. Acta Psychiatr. Scand. 42, 264-271. doi: 10.1111/j.16000447.1966.tb01931.x

Bushmann, M., Dobmeyer, S. M., Leeker, L., and Perlmutter, J. S. (1989). Swallowing abnormalities and their response to treatment in Parkinson's disease. Neurology 39, 1309-1314. doi: 10.1212/WNL.39.10.1309

Camicioli, R., Lea, E., Nutt, J. G., Sexton, G., and Oken, B. S. (2001). Methylphenidate increases the motor effects of L-Dopa in Parkinson's disease: a pilot study. Clin. Neuropharmacol. 24, 208-213. doi: 10.1097/00002826200107000-00003

Chan, P. L., Nutt, J. G., and Holford, N. H. (2004). Modeling the shortand long-duration responses to exogenous levodopa and to endogenous levodopa production in Parkinson's disease. J. Pharmacokinet. Pharmacodyn. 31, 243-268. doi: 10.1023/B:JOPA.0000039566.75368.59

Chung, K. A., Carlson, N. E., and Nutt, J. G. (2005). Short-term paroxetine treatment does not alter the motor response to levodopa in PD. Neurology 64, 1797-1798. doi: 10.1212/01.WNL.0000161841.41885.80

Chung, K. A., Lobb, B. M., Nutt, J. G., McNames, J., and Horak, F. (2010). Objective measurement of dyskinesia in Parkinson's disease using a force plate. Mov. Disord. 25, 602-608. doi: 10.1002/mds.22856

Connolly, B. S., and Lang, A. E. (2014). Pharmacological treatment of Parkinson disease: a review. JAMA 311, 1670-1683. doi: 10.1001/jama.2014.3654
Cotzias, G. C., van Woert, H. H., and Schiffer, L. M. (1967). Aromatic amino acids and modifications of parkinsonism. N. Engl. J. Med. 276, 374-379. doi: 10.1056/NEJM196702162760703

Davis, T. L., Brughitta, G., Baronti, F., and Mouradian, M. M. (1991). Acute effects of pulsatile levodopa administration on central dopamine pharmacodynamics. Neurology 41, 630-633. doi: 10.1212/WNL.41.5.630

Degkwitz, R., Frowein, R., Kulenkampff, C., and Mohs, U. (1960). Uber die Wirkungen des L-Dopa beim Menschen und deren Beeinflussung durch Reserpin, Chlorpromazin, Iproniazid und Vitamin B6 [On the effects of L-dopa in man and their modification by reserpine, chlorpromazine, iproniazid and vitamin B6]. Klin. Wochenschr. 38, 120-123. doi: 10.1007/BF02189076

Durso, R., Evans, J. E., Josephs, E., Szabo, G., Evans, B., Fernandez, H. H., et al. (2000). Variable absorption of carbidopa affects both peripheral and central levodopa metabolism. J. Clin. Pharmacol. 40, 854-860. doi: $10.1177 / 00912700022009585$

Durso, R., Evans, J. E., Josephs, E., Szabo, G. K., Evans, B. A., Handler, J. S., et al. (1997). Central levodopa metabolism in Parkinson's disease after administration of stable isotope-labeled levodopa. Ann. Neurol. 42, 300-304. doi: 10.1002/ana.410420305

Fabbrini, G., Juncos, J., Mouradian, M. M., Serrati, C., and Chase, T. N. (1987). Levodopa pharmacokinetic mechanisms and motor fluctuations in Parkinson's disease. Ann. Neurol. 21, 370-376. doi: 10.1002/ana.410210409

Fabbrini, G., Mouradian, M. M., Juncos, J. L., Schlegel, J., Mohr, E., and Chase, T. N. (1988). Motor fluctuations in Parkinson's disease: central pathophysiological mechanisms, Part I. Ann. Neurol. 24, 366-371. doi: 10.1002/ana.410240303

Fasano, V. A., Urciuoli, R., Broggi, G., Cannella, M., and Lombard, G. F. (1970b). Observations cliniques sur l'action de la levo-dopa par voie intraveineuse et par voie orale dans le traitement de la maladie de Parkinson (135 cas) [Clinical remarks on the action of intravenous and oral levodopa in the treatment of Parkinson's disease (135 cases)]. Neurochirurgie 16, 171-178.

Fasano, V. A., Urciuoli, R., Broggi, G., and Lombard, G. F. (1970a). Osservazioni sull'impiego della Levo-Dopa nel trattamento del morbo di Parkinson (188 casi) [Use of levodopa in the treatment of Parkinson's disease (188 cases)]. Minerva Neurochir. 14, 245-249.

Fehling, C. (1966). Treatment of Parkinson's syndrome with L-dopa. A double blind study. Acta Neurol. Scand. 42, 367-372. doi: 10.1111/j.16000404.1966.tb01188.x

Feigin, A., Fukuda, M., Dhawan, V., Przedborski, S., Jackson-Lewis, V., Mentis, M. J., et al. (2001). Metabolic correlates of levodopa response in Parkinson's disease. Neurology 57, 2083-2088. doi: 10.1212/WNL.57.11.2083

Feigin, A., Ghilardi, M. F., Carbon, M., Edwards, C., Fukuda, M., Dhawan, V., et al. (2003). Effects of levodopa on motor sequence learning in Parkinson's disease. Neurology 60, 1744-1749. doi: 10.1212/01.WNL.0000072263.03608.42

Feigin, A., Ghilardi, M. F., Fukuda, M., Mentis, M. J., Dhawan, V., Barnes, A., et al. (2002). Effects of levodopa infusion on motor activation responses in Parkinson's disease. Neurology 59, 220-226. doi: 10.1212/WNL.59.2.220

Friedhoff, A. J., Hekimian, L., Alpert, M., and Tobach, E. (1963). Dihydroxyphenylalanine in extrapyramidal disease. J. Am. Med. Assoc. 184, 285-286. doi: 10.1001/jama.1963.73700170010010c

Gancher, S. T., Nutt, J. G., and Woodward, W. (1988). Response to brief levodopa infusions in parkinsonian patients with and without motor fluctuations. Neurology 38, 712-716. doi: 10.1212/WNL.38.5.712

Gancher, S. T., Nutt, J. G., and Woodward, W. R. (1987). Peripheral pharmacokinetics of levodopa in untreated, stable, and fluctuating parkinsonian patients. Neurology 37, 940-944. doi: 10.1212/WNL.37.6.940

Gerstenbrand, F., and Pateisky, K. (1963). Beitrag zur Therapie und Rehabilitation des Parkinsonschen Syndroms [Contribution to the therapy and rehabilitation of Parkinson's syndrome]. Wien. Z. Nervenheilkd. Grenzgeb. 21, 124-131.

Gerstenbrand, F., and Prosenz, P. (1965). Über die Behandlung des Parkinsonsyndroms mit Monoaminoxydasehemmern allein und in Kombination mit L-dopa [On the treatment of Parkinson's syndrome with monoamine oxidase inhibitors alone and in combination with L-dopa]. Praxis 54, 1373-1377.

Gerstenbrand, G., and Pateisky, K. (1962). Über die Wirkung von 1-Dopa auf die motorischen Störungen beim Parkinson-Syndrom [On the effects of I-DOPA on motor disorders in Parkinson's syndrome. An electromyographic study.]. Wien. Z. Nervenheilkd. Grenzgeb. 20, 90-100. 
Gillin, J. C., Post, R. M., Wyatt, R. J., Goodwin, F. K., Snyder, F., Bunney, W. E., et al. (1973). REM inhibitory effect of L-DOPA infusion during human sleep. Electroencephalogr. Clin. Neurophysiol. 35, 181-186. doi: 10.1016/00134694(73)90174-0

Goetz, C. G., Vogel, C., Tanner, C. M., and Stebbins, G. T. (1998). Early dopaminergic drug-induced hallucinations in parkinsonian patients. Neurology 51, 811-814. doi: 10.1212/WNL.51.3.811

Goldstein, D. S., Swoboda, K. J., Miles, J. M., Coppack, S. W., Aneman, A., Holmes, C., et al. (1999). Sources and physiological significance of plasma dopamine sulfate. J. Clin. Endocrinol. Metab. 84, 2523-2531. doi: 10.1210/jcem.84. 7.5864

Gordon, M., Markham, J., Hartlein, J. M., Koller, J. M., Loftin, S., and Black, K. J. (2007). Intravenous levodopa administration in humans based on a two-compartment kinetic model. J. Neurosci. Methods 159, 300-307. doi: 10.1016/j.jneumeth.2006.07.010

Gragnoli, G., Palazzuoli, V., Favilli, R., Tanganelli, I., and Migliarese, G. (1977). Dopaminergic stimulation of $\mathrm{HGH}$ in diabetes mellitus and in obesity. Acta Diabetol. Lat. 14, 137-143. doi: 10.1007/BF02581401

Gründig, E., Gerstenbrand, F., Bruck, J., Gnad, H., Prosenz, P., and Teuflmayr, R. (1969). Der Einfluß der Veräbreichung von Aminosäuren, speziell von L-Dopa und $\alpha$-Methyldopa, auf die Zusammensetzung des Liquor cerebrospinalis bei extrapyramidalen Syndromen. I. Veränderungen der Liquorzusammensetzung nach L-Dopa-Gaben bei Parkinson-Patienten und Gesunden [The effect of the administration of amino acids, especially of L-dopa and alpha-methyldopa, on the composition of cerebrospinal fluid in extrapyramidal syndromes. I. Alterations of cerebrospinal fluid in patients with Parkinson's disease and normals]. Dtsch. Z. Nervenheilkd. 196, 236-265. doi: 10.1007/BF00244111

Hardie, R. J., Lees, A. J., and Stern, G. M. (1984). On-off fluctuations in Parkinson's disease: a clinical and neuropharmacological study. Brain 107, 487-506. doi: 10.1093/brain/107.2.487

Hardie, R. J., Malcolm, S. L., Lees, A. J., Stern, G. M., and Allen, J. G. (1986). The pharmacokinetics of intravenous and oral levodopa in patients with Parkinson's disease who exhibit on-off fluctuations. Br. J. Clin. Pharmacol. 22, 429-436. doi: 10.1111/j.1365-2125.1986.tb02913.x

Hartvig, P., Agren, H., Reibring, L., Tedroff, J., Bjurling, P., Kihlberg, T., et al. (1991). Brain kinetics of L-[beta-11C]dopa in humans studied by positron emission tomography. J. Neural Transm. Gen. Sect. 86, 25-41. doi: 10.1007/BF01250373

Hashizume, K., Yamatodani, A., Yamamoto, T., Ogihara, T., Kumahara, Y., and Wada, H. (1987). Effects of oral and intravenous administrations of dopamine and L-dopa on plasma levels of two isomers of dopamine sulfate in man. Life Sci. 41, 2697-2704. doi: 10.1016/0024-3205(87)90462-0

Henry, G. M., Buchsbaum, M., and Murphy, D. L. (1976). Intravenous 1-DOPA plus carbidopa in depressed patients: average evoked response, learning, and behavioral changes. Psychosom. Med. 38, 95-105. doi: 10.1097/00006842197603000-00003

Hirano, S., Asanuma, K., Ma, Y., Tang, C., Feigin, A., Dhawan, V., et al. (2008). Dissociation of metabolic and neurovascular responses to levodopa in the treatment of Parkinson's disease. J. Neurosci. 28, 4201-4209. doi: 10.1523/JNEUROSCI.0582-08.2008

Hirschmann, J., and Mayer, K. (1964a). Neue Wege zur Beeinflussung extrapyramidal-motorischer Störungen [New means of controlling extrapyramidal motor disorders]. Arzneimittelforschung 14(Suppl.), 599-601.

Hirschmann, J., and Mayer, K. (1964b). Zur Beeinflussung der Akinese und anderer extrapyramidal-motorischer Störungen mit L-Dopa (LDihydroxyphenylalanin) [The effect of L-dopa (L-dihydroxyphenylalanine) on akinesia and other extrapyramidal motor disorders]. Dtsch. Med. Wochenschr. 89, 1877-1880. doi: 10.1055/s-0028-1113210

Horai, T., Nishiyama, T., Yamamoto, H., and Hanaoka, K. (2002). [High dose L-dopa infusion during general anesthesia for gastrectomy in a patient with parkinsonism]. Masui 51, 42-45. Available online at: https://sciencescape.org/ paper/11840662

Hornykiewicz, O. (1963). Die Topische Lokalisation und das Verhalten von Noradrenalin und Dopamin in der Substantia Nigra des normalen und Parkinsonkranken Menschen. Wien. Klin. Wochenschr. 75, 309-312.

Ingvarsson, C. G. (1965a). [Orientative clinical trials on the effects of dihydroxyphenylalanine (1-dopa) in endogenous depression]. Arzneimittelforschung 15, 849-852.
Ingvarsson, G. (1965b). [L-dopa and bronchial asthma. Preliminary report]. Nord. Med. 74, 1166-1167.

Jaffe, M. J., Bruno, G., Campbell, G., Lavine, R. A., Karson, C. N., and Weinberger, D. R. (1987). Ganzfeld electroretinographic findings in parkinsonism: untreated patients and the effect of levodopa intravenous infusion. J. Neurol. Neurosurg. Psychiatrry 50, 847-852. doi: 10.1136/jnnp.50.7.847

Jenner, P., McCreary, A. C., and Scheller, D. K. A. (2011). Continuous drug delivery in early- and late-stage Parkinson's disease as a strategy for avoiding dyskinesia induction and expression. J. Neural Transm. (Vienna) 118, 1691-1702. doi: 10.1007/s00702-011-0703-9

Juncos, J. L., Mouradian, M. M., Fabbrini, G., and Chase, T. N. (1990). "Levodopa infusion therapy," in Therapy of Parkinson's Disease, eds W. C. Koller and G. Paulson (New York, NY: Marcel Dekker), 185-203.

Juncos, J. L., Mouradian, M. M., Fabbrini, G., Serrati, C., and Chase, T. N. (1987). Levodopa methyl ester treatment of Parkinson's disease. Neurology 37, 1242-1245. doi: 10.1212/WNL.37.7.1242

Ko, J. H., Mure, H., Tang, C. C., Ma, Y., Dhawan, V., Spetsieris, P., et al. (2013). Parkinson's disease: increased motor network activity in the absence of movement. J. Neurosci. 33, 4540-4549. doi: 10.1523/JNEUROSCI.502412.2013

Kobari, M., Fukuuchi, Y., Shinohara, T., Nogawa, S., and Takahashi, K. (1992). Local cerebral blood flow and its response to intravenous levodopa in progressive supranuclear palsy. Comparison with Parkinson's disease. Arch. Neurol. 49, 725-730. doi: 10.1001/archneur.1992.00530310071014

Kobari, M., Fukuuchi, Y., Shinohara, T., Obara, K., and Nogawa, S. (1995). Levodopa-induced local cerebral blood flow changes in Parkinson's disease and related disorders. J. Neurol. Sci. 128, 212-218. doi: 10.1016/0022510X(94)00237-I

Kompoliti, K., Adler, C. H., Raman, R., Pincus, J. H., Leibowitz, M. T., Ferry, J. J., et al. (2002). Gender and pramipexole effects on levodopa pharmacokinetics and pharmacodynamics. Neurology 58, 1418-1422. doi: 10.1212/WNL.58.9.1418

LeWitt, P. A., Jennings, D., Lyons, K. E., Pahwa, R., Rabinowicz, A. L., Wang, J., et al. (2009). Pharmacokinetic-pharmacodynamic crossover comparison of two levodopa extension strategies. Mov. Disord. 24, 1319-1324. doi: $10.1002 /$ mds. 22587

Lucas, C., Oliver, C., Jaquet, P., and Vague, J. (1975). [Anomalies of corticotropin secretion in chromophobe adenomas]. Ann. Endocrinol. (Paris) 36, 179-184.

Maricle, R. A., Nutt, J. G., and Carter, J. H. (1995a). Mood and anxiety fluctuation in Parkinson's disease associated with levodopa infusion: preliminary findings. Mov. Disord. 10, 329-332. doi: 10.1002/mds.870100316

Maricle, R. A., Nutt, J. G., Valentine, R. J., and Carter, J. H. (1995b). Dose-response relationship of levodopa with mood and anxiety in fluctuating Parkinson's disease: a double-blind, placebo-controlled study. Neurology 45, 1757-1760. doi: 10.1212/WNL.45.9.1757

Maricle, R. A., Valentine, R. J., Carter, J., and Nutt, J. G. (1998). Mood response to levodopa infusion in early Parkinson's disease. Neurology 50, 1890-1892. doi: 10.1212/WNL.50.6.1890

Marion, M. H., Stocchi, F., Quinn, N. P., Jenner, P., and Marsden, C. D. (1986). Repeated levodopa infusions in fluctuating Parkinson's disease: clinical and pharmacokinetic data. Clin. Neuropharmacol. 9, 165-181. doi: 10.1097/00002826-198604000-00008

Matussek, N., Pohlmeier, H., and Rüther, E. (1966). [The effects of dopa on inhibited depressions]. Klin. Wochenschr. 44, 727-728. doi: 10.1007/BF01790804

McGeer, P. L., and Zeldowicz, L. R. (1964). Administration of Dihydroxyphenylalanine to Parkinsonian Patients. Can. Med. Assoc. J. 90, 463-466.

Metman, L. V., Del Dotto, P., LePoole, K., Konitsiotis, S., Fang, J., and Chase, T. N. (1999). Amantadine for levodopa-induced dyskinesias: a 1-year follow-up study. Arch. Neurol. 56, 1383-1386. doi: 10.1001/archneur.56.11.1383

Metman, L. V., van den Munckhof, P., Klaassen, A. A., Blanchet, P., Mouradian, M. M., and Chase, T. N. (1997). Effects of supra-threshold levodopa doses on dyskinesias in advanced Parkinson's disease. Neurology 49, 711-713. doi: 10.1212/WNL.49.3.711

Metzel, E. (1965). Über die Störung des Raumsinns beim Parkinson-Syndrom [On disturbances in space perception caused by Parkinson's syndrome]. Dtsch. Med. Wochenschr. 90, 1955-1957. doi: 10.1055/s-0028-1113454 
Moorthy, S., Grendahl, H., Andersen, A., and Müller, C. (1972). The haemodynamic effect of intravenous injection of levodopa. Acta Med. Scand. 191, 451-454.

Mouradian, M. M., Heuser, I. J., Baronti, F., and Chase, T. N. (1990). Modification of central dopaminergic mechanisms by continuous levodopa therapy for advanced Parkinson's disease. Ann. Neurol. 27, 18-23. doi: 10.1002/ana.410270105

Mouradian, M. M., Juncos, J. L., Fabbrini, G., and Chase, T. N. (1987a). Motor fluctuations in Parkinson's disease: pathogenetic and therapeutic studies. Ann. Neurol. 22, 475-479. doi: 10.1002/ana.410220406

Mouradian, M. M., Juncos, J. L., Fabbrini, G., Schlegel, J., Bartko, J. J., and Chase, T. N. (1988). Motor fluctuations in Parkinson's disease: central pathophysiological mechanisms, Part, I. I. Ann. Neurol. 24, 372-378. doi: 10.1002/ana.410240304

Mouradian, M. M., Juncos, J. L., Serrati, C., Fabbrini, G., Palmeri, S., and Chase, T. N. (1987b). Exercise and the antiparkinsonian response to levodopa. Clin. Neuropharmacol. 10, 351-355. doi: 10.1097/00002826-198708000-00005

Muhlack, S., Woitalla, D., Welnic, J., Twiehaus, S., Przuntek, H., and Müller, T. (2004). Chronic levodopa intake increases levodopa plasma bioavailability in patients with Parkinson's disease. Neurosci. Lett. 363, 284-287. doi: 10.1016/j.neulet.2004.04.012

Mure, H., Tang, C. C., Argyelan, M., Ghilardi, M. F., Kaplitt, M. G., Dhawan, V., et al. (2012). Improved sequence learning with subthalamic nucleus deep brain stimulation: evidence for treatment-specific network modulation. J. Neurosci. 32, 2804-2813. doi: 10.1523/JNEUROSCI.4331-11.2012

Nardini, M., Fieschi, C., Agnoli, A., Arcioli, I., and Zanette, E. (1970). [The trial of intravenous L-DOPA in patients with Parkinson's disease]. Rivista Neurol. 40, 75-85.

NIOSH, Biovia (2015). "RTECS ${ }^{\circledR}$ (Registry of toxic effects of chemical substances)," in Canadian Centre for Occupational Health and Safety. Available online at: http://ccinfoweb.ccohs.ca/rtecs/search.html

Nisijima, K., Noguti, M., and Ishiguro, T. (1997). Intravenous injection of levodopa is more effective than dantrolene as therapy for neuroleptic malignant syndrome. Biol. Psychiatry 41, 913-914. doi: 10.1016/S0006-3223(96)00519-7

Nutt, J. G., Carter, J. H., Lea, E. S., and Sexton, G. J. (2002). Evolution of the response to levodopa during the first 4 years of therapy. Ann. Neurol. 51, 686-693. doi: 10.1002/ana.10189

Nutt, J. G., Carter, J. H., Lea, E. S., and Woodward, W. R. (1997a). Motor fluctuations during continuous levodopa infusions in patients with Parkinson's disease. Mov. Disord. 12, 285-292. doi: 10.1002/mds.870120304

Nutt, J. G., Carter, J. H., Van Houten, L., and Woodward, W. R. (1997b). Short- and long-duration responses to levodopa during the first year of levodopa therapy. Ann. Neurol. 42, 349-355. doi: 10.1002/ana.410420311

Nutt, J. G., Carter, J. H., Woodward, W., Hammerstad, J. P., and Gancher, S. T. (1993). Does tolerance develop to levodopa? Comparison of 2- and 21-H levodopa infusions. Mov. Disord. 8, 139-143. doi: 10.1002/mds.870080204

Nutt, J. G., Carter, J. H., and Woodward, W. R. (1994). Effect of brief levodopa holidays on the short-duration response to levodopa: evidence for tolerance to the antiparkinsonian effects. Neurology 44, 1617-1622. doi: 10.1212/WNL.44.9.1617

Nutt, J. G., Carter, J. H., and Woodward, W. R. (1995). Long-duration response to levodopa. Neurology 45, 1613-1616. doi: 10.1212/WNL.45.8.1613

Nutt, J. G., Gancher, S. T., and Woodward, W. R. (1988). Does an inhibitory action of levodopa contribute to motor fluctuations? Neurology 38, 1553-1557. doi: 10.1212/WNL.38.10.1553

Nutt, J. G., and Nygaard, T. G. (2001). Response to levodopa treatment in doparesponsive dystonia. Arch. Neurol. 58, 905-910. doi: 10.1001/archneur.58.6.905

Nutt, J. G., Rufener, S. L., Carter, J. H., Anderson, V. C., Pahwa, R., Hammerstad, J. P., et al. (2001). Interactions between deep brain stimulation and levodopa in Parkinson's disease. Neurology 57, 1835-1842. doi: 10.1212/WNL.57.10.1835

Nutt, J. G., and Woodward, W. R. (1986). Levodopa pharmacokinetics and pharmacodynamics in fluctuating parkinsonian patients. Neurology 36, 739-744. doi: 10.1212/WNL.36.6.739

Nutt, J. G., Woodward, W. R., and Anderson, J. L. (1985). The effect of carbidopa on the pharmacokinetics of intravenously administered levodopa: the mechanism of action in the treatment of parkinsonism. Ann. Neurol. 18, 537-543. doi: 10.1002/ana.410180505

Nutt, J. G., Woodward, W. R., Carter, J. H., and Gancher, S. T. (1992). Effect of long-term therapy on the pharmacodynamics of levodopa.
Relation to on-off phenomenon. Arch. Neurol. 49, 1123-1130. doi: 10.1001/archneur.1992.00530350037016

Nutt, J. G., Woodward, W. R., Hammerstad, J. P., Carter, J. H., and Anderson, J. L. (1984). The “on-off” phenomenon in Parkinson's disease. Relation to levodopa absorption and transport. N. Engl. J. Med. 310, 483-488. doi: 10.1056/NEJM198402233100802

Ogawa, E., Sakakibara, R., Kishi, M., and Tateno, F. (2012). Constipation triggered the malignant syndrome in Parkinson's disease. Neurol. Sci. 33, 347-350. doi: 10.1007/s10072-011-0710-5

Oishi, M., Mochizuki, Y., Hara, M., Du, C. M., and Takasu, T. (1996). Effects of intravenous L-dopa on P300 and regional cerebral blood flow in parkinsonism. Int. J. Neurosci. 85, 147-154. doi: 10.3109/00207459608986359

Pare, C. M., and Sandler, M. (1959). A clinical and biochemical study of a trial of iproniazid in the treatment of depression. J. Neurol. Neurosurg. Psychiatry 22, 247-251. doi: 10.1136/jnnp.22.3.247

Pazzagli, A., and Amaducci, L. (1966). [Clinical experimentation of DOPA in Parkinsonian syndromes]. Riv. Neurobiol. 12, 138-145.

Peppe, A., De Angelis, D., Tolli, V. S., Rizzo, P. A., and Scoppetta, C. (1991). [Intravenous infusion of L-dopa: current prospective therapies]. Riv. Neurol. 61, 197-200.

Poewe, W. (1993). "L-dopa in Parkinson's disease: mechanisms of action and pathophysiology of late failure," in Parkinson's Disease and Movement Disorders, eds J. Jankovic and E. Tolosa (Baltimore, MD: Williams and Wilkins), 103-113.

Pullman, S. L., Watts, R. L., Juncos, J. L., Chase, T. N., and Sanes, J. N. (1988). Dopaminergic effects on simple and choice reaction time performance in Parkinson's disease. Neurology 38, 249-254. doi: 10.1212/WNL.38.2.249

Puritz, R., Lightman, S. L., Wilcox, C. S., Forsling, M., and Bannister, R. (1983). Blood pressure and vasopressin in progressive autonomic failure. Response to postural stimulation, L-dopa and naloxone. Brain 106(Pt 2), 503-511. doi: 10.1093/brain/106.2.503

Quinn, N., Marsden, C. D., and Parkes, J. D. (1982). Complicated response fluctuations in Parkinson's disease: response to intravenous infusion of levodopa. Lancet 2, 412-415. doi: 10.1016/S0140-6736(82)90442-1

Quinn, N., Parkes, J. D., and Marsden, C. D. (1984). Control of on/off phenomenon by continuous intravenous infusion of levodopa. Neurology 34, 1131-1136. doi: 10.1212/WNL.34.9.1131

Rascol, O., Nutt, J. G., Blin, O., Goetz, C. G., Trugman, J. M., Soubrouillard, C., et al. (2001). Induction by dopamine D1 receptor agonist ABT-431 of dyskinesia similar to levodopa in patients with Parkinson disease. Arch. Neurol. 58, 249-254. doi: 10.1001/archneur.58.2.249

Rinne, U. K., and Sonninen, V. (1968). A double blind study of L-Dopa treatment in Parkinson's disease. Eur. Neurol. 1, 180-191. doi: 10.1159/000113660

Roberts, J., Waller, D. G., O’Shea, N., Macklin, B. S., and Renwick, A. G. (1995). The effect of selegiline on the peripheral pharmacokinetics of levodopa in young volunteers. Br. J. Clin. Pharmacol. 40, 404-406.

Robertson, D. R. C., Wood, N. D., Everest, H., Monks, K., Waller, D. G., Renwick, A. G., et al. (1989). The effect of age on the pharmacokinetics of levodopa administered alone and in the presence of carbidopa. Br. J. Clin. Pharmacol. 28, 61-69. doi: 10.1111/j.1365-2125.1989.tb03506.x

Rodriguez, M., Lera, G., Vaamonde, J., Luquin, M. R., and Obeso, J. A. (1994). Motor response to apomorphine and levodopa in asymmetric Parkinson's disease. J. Neurol. Neurosurg. Psychiatry 57, 562-566. doi: 10.1136/jnnp.57.5.562

Roe, D. L. (1997). From DOPA to Parkinson's disease: the early history of dopamine research. J. Hist. Neurosci. 6, 291-301. doi: 10.1080/09647049709525715

Rosin, A. J., Devereux, D., Eng, N., and Calne, D. B. (1979). Parkinsonism with 'onoff' phenomena. Intravenous treatment with levodopa after major abdominal surgery. Arch. Neurol. 36, 32-34. doi: 10.1001/archneur.1979.005003700 62014

Ruggieri, S., Stocchi, F., Carta, A., Bravi, D., Bragoni, M., Giorgi, L., et al. (1988). Comparison between L-dopa and lisuride intravenous infusions: a clinical study. Mov. Disord. 3, 313-319. doi: 10.1002/mds.870030405

Sage, J. I., and Mark, M. H. (1991). Nighttime levodopa infusions to treat motor fluctuations in advanced Parkinson's disease: preliminary observations. Ann. Neurol. 30, 616-617. doi: 10.1002/ana.410300417

Sasahara, K., Nitanai, T., Habara, T., Morioka, T., and Nakajima, E. (1980a). Dosage form design for improvement of bioavailability of levodopa III: influence of dose on pharmacokinetic behavior of levodopa in 
dogs and Parkinsonian patients. J. Pharm. Sci. 69, 1374-1378. doi: 10.1002/jps.2600691205

Sasahara, K., Nitanai, T., Habara, T., Morioka, T., and Nakajima, E. (1980b). Dosage form design for improvement of bioavailability of levodopa II: bioavailability of marketed levodopa preparations in dogs and parkinsonian patients. J. Pharm. Sci. 69, 261-265. doi: 10.1002/jps.26006 90304

Schuh, L. A., and Bennett, J. P. Jr. (1993). Suppression of dyskinesias in advanced Parkinson's disease. I. Continuous intravenous levodopa shifts dose response for production of dyskinesias but not for relief of parkinsonism in patients with advanced Parkinson's disease. Neurology 43, 1545-1550. doi: 10.1212/WNL.43.8.1545

Shinoda, M., Sakamoto, M., Shindo, Y., Ando, Y., and Tateda, T. (2013). [Case of neuroleptic malignant syndrome following open heart surgery for thoracic aortic aneurysm with parkinson's disease]. Masui 62, 1453-1456. Available online at: https://sciencescape.org/paper/179380186

Shoulson, I., Glaubiger, G. A., and Chase, T. N. (1975). On-off response. Clinical and biochemical correlations during oral and intravenous levodopa administration in parkinsonian patients. Neurology 25, 1144-1148. doi: 10.1212/WNL.25.12.1144

Siddiqi, S. H., Creech, M. L., and Black, K. J. (2015). Orthostatic stability with intravenous levodopa. PeerJ 3:e1198. doi: 10.7717/peerj.1198

Skalabrin, E. J., Laws, E. R. Jr., and Bennett, J. P. Jr. (1998). Pallidotomy improves motor responses and widens the levodopa therapeutic window in Parkinson's disease. Mov. Disord. 13, 775-781. doi: 10.1002/mds.870130504

Sohn, Y. H., Metman, L. V., Bravi, D., Linfante, I., Aotsuka, A., Mouradian, M. M., et al. (1994). Levodopa peak response time reflects severity of dopamine neuron loss in Parkinson's disease. Neurology 44, 755-757. doi: 10.1212/WNL.44. 4.755

Souvatzoglou, A., von Werder, K., and Bottermann, P. (1973). The effect of intravenous L-dopa on growth hormone and luteinizing hormone levels in man. Acta Endocrinol. 73, 259-265. doi: 10.1530/acta.0.0730259

Stocchi, F., Ruggieri, S., Brughitta, G., and Agnoli, A. (1986). Problems in daily motor performances in Parkinson's disease: the continuous dopaminergic stimulation. J. Neural Transm. Suppl. 22, 209-218.

Stocchi, F., Ruggieri, S., Carta, A., Ryatt, J., Quinn, N., Jenner, P., et al. (1992). Intravenous boluses and continuous infusions of L-dopa methyl ester in fluctuating patients with Parkinson's disease. Mov. Disord. 7, 249-256. doi: $10.1002 / \mathrm{mds} .870070311$

Sunami, M., Nishikawa, T., Yorogi, A., and Shimoda, M. (2000). Intravenous administration of levodopa ameliorated a refractory akathisia case induced by interferon-alpha. Clin. Neuropharmacol. 23, 59-61. doi: 10.1097/00002826200001000-00012

Takahara, J., Yunoki, S., Hosogi, H., Yakushiji, W., Kageyama, J., and Ofuji, T. (1980). Concomitant increases in serum growth hormone and hypothalamic somatostatin in rats after injection of $\gamma$-aminobutyric acid, aminooxyacetic acid, or $\gamma$-hydroxybutyric acid. Endocrinology 106, 343-347. doi: 10.1210/endo106-1-343

Takeuchi, S., Sugiyama, Y., Mano, T., Iwase, S., and Matsukawa, T. (1993). Effect of L-dopa on human muscle sympathetic nerve activity. Environ. Med. 37, 99-102.

Takubo, H., Harada, T., Hashimoto, T., Inaba, Y., Kanazawa, I., Kuno, S., et al. (2003). A collaborative study on the malignant syndrome in Parkinson's disease and related disorders. Parkinsonism Relat. Disord. 9(Suppl. 1), S31-S41. doi: 10.1016/S1353-8020(02)00122-0

Tedroff, J., Aquilonius, S. M., Hartvig, P., Bredberg, E., Bjurling, P., and Langstrom, B. (1992). Cerebral uptake and utilization of therapeutic [beta- ${ }^{11}$ C]-L-DOPA in Parkinson's disease measured by positron emission tomography. Relations to motor response. Acta Neurol. Scand. 85, 95-102. doi: 10.1111/j.16000404.1992.tb04005.x

Tedroff, J., Aquilonius, S. M., Laihinen, A., Rinne, U., Hartvig, P., Anderson, J., et al. (1990). Striatal kinetics of $\left[{ }^{11} \mathrm{C}\right]-(+)$-nomifensine and 6-[18F]fluoro-L-dopa in Parkinson's disease measured with positron emission tomography. Acta Neurol. Scand. 81, 24-30. doi: 10.1111/j.1600-0404.1990.tb00926.x

Tedroff, J., Pedersen, M., Aquilonius, S. M., Hartvig, P., Jacobsson, G., and Langstrom, B. (1996). Levodopa-induced changes in synaptic dopamine in patients with Parkinson's disease as measured by $\left[{ }^{11} \mathrm{C}\right]$ raclopride displacement and PET. Neurology 46, 1430-1436. doi: 10.1212/WNL.46.5.1430

Torstenson, R., Hartvig, P., Långström, B., Westerberg, G., and Tedroff, J. (1997). Differential effects of levodopa on dopaminergic function in early and advanced Parkinson's disease. Ann. Neurol. 41, 334-340. doi: 10.1002/ana.410410308

Tzavellas, O., and Umbach, W. (1967). [Clinical and electromyographic controls of the effect of dopamine in parkinsonian patients]. Arch. Psychiatr. Nervenkr. $209,227-240$.

Umbach, W. (1966). [L-dopa and amphetamine treatment of acinetic Parkinsonism patients with and without stereotaxic surgery]. Beitr. Neurochir. 13, 45-51.

Umbach, W., and Baumann, D. (1964). [the efficacy of L-DOPA in Parkinson patients with and without stereotactic brain surgery]. Arch. Psychiatr. Nervenkr. 205, 281-292. doi: 10.1007/BF00395715

Umbach, W., and Tzavellas, O. (1965). Zur Behandlung akinestischer Begleitsymptome beim Parkinson-Syndrom [On the treatment of akinetic symptoms in Parkinson's syndrome]. Dtsch. Med. Wochenschr. 90, 1941-1944. doi: 10.1055/s-0028-1113450

Verhagen Metman, L., Del Dotto, P., van den Munckhof, P. M. P., Fang, J., Mouradian, M. M., and Chase, T. N. (1998b). Amantadine as treatment for dyskinesias and motor fluctuations in Parkinson's disease. Neurology 50, 1323-1326. doi: 10.1212/WNL.50.5.1323

Verhagen Metman, L., Del Dotto, P., van den Munckhof, P., Fang, J., Mouradian, M. M., and Chase, T. N. (1998a). Amantadine as treatment for dyskinesias and motor fluctuations in Parkinson's disease. Neurology 50, 1323-1326. doi: 10.1212/WNL.50.5.1323

Völler, G. W. (1968). [A contribution to the biochemical treatment of the akinetic type of the Parkinson's syndrome]. Med. Welt 5, 338-341.

Worth, D., Harvey, J., Brown, J., and Lee, M. (1988). The effects of intravenous Ldopa on plasma renin activity, renal function, and blood pressure in man. Eur. J. Clin. Pharmacol. 35, 137-141. doi: 10.1007/BF00609242

Zsigmond, P., Dernroth, N., Kullman, A., Augustinsson, L. E., and Dizdar, N. (2012). Stereotactic microdialysis of the basal ganglia in Parkinson's disease. J. Neurosci. Methods 207, 17-22. doi: 10.1016/j.jneumeth.2012.02.021

Conflict of Interest Statement: The authors declare that the research was conducted in the absence of any commercial or financial relationships that could be construed as a potential conflict of interest.

Kevin J. Black is Sponsor-Investigator for an Investigational New Drug application for intravenous levodopa (U.S. FDA).

Copyright (c) 2016 Siddiqi, Abraham, Geiger, Karimi, Perlmutter and Black. This is an open-access article distributed under the terms of the Creative Commons Attribution License (CC BY). The use, distribution or reproduction in other forums is permitted, provided the original author(s) or licensor are credited and that the original publication in this journal is cited, in accordance with accepted academic practice. No use, distribution or reproduction is permitted which does not comply with these terms. 